\title{
İstanbul'da Bir Acem Matbaası: Kitapçı Tahir ve Ahter
}

\author{
GüllüYıldız*
}

\begin{abstract}
A Persian Printing House in Istanbul: Tāhir the Bookman and Akhtar
Abstract Muhammad Tâhir Tabrizî, or Tâhir the Bookman in Ottoman sources, migrated to Istanbul and spent the rest of his life there. As a merchant from Tabriz he was well-known especially in the Iranian community in Istanbul and for those Iranians who came to visit him from outside. He rose to prominence in the Ottoman press and Ottoman-Iranian relations when he published Akhtar, the first and the most important Persian newspaper ever published out of Iran in the twenty year period from 1876 to 1896 . Studies on Akhtar which have flourished recently say only a few words about Tâhir, the owner, manager and also a writer of the newspaper. This study which aims to fill this gap, brings together the information on his biography, describes his publishing activities, and examines his relation to the Ottoman government and Iran.
\end{abstract}

Keywords: Muhammad Tāhir Tabrizī, Tāhir the Bookman, Akhtar, Ottoman Press

Muhammed Tahir Tebrizî, Osmanlı kaynaklarındaki şekli ile Kitapçı Tahir Efendi İstanbul'a göçmüş, ömrünün kalanını burada geçirmiş Tebrizli bir tüccar olarak özellikle İstanbul'da mukim ya da bir şekilde İstanbul'a yolu düşen hemen her İranlının yakından tanıdığı bir isimdir. ${ }^{1}$ Ancak zaman zaman kesintiye uğramakla birlikte yirmi yıllık bir yayın hayatına sahip, İran dışında yayınlanmış

* Marmara Üniversitesi

1 Bu çalışmanın ilk bulguları, "Osmanlı Matbuatının Farklı Bir Yüzü: Muhammed Tâhir Tebrizî” başlıklı bildiriyle Türk Basın Tarihi Uluslararası Sempozyumu’nda (2122 Ekim 2016, Elazı̆̆) sunulmuştur. 
Farsça gazetelerin ilk ve en önemlilerinden biri kabul edilen Ahter'i (1876-1896) yayınladığında hem Osmanlı matbuat hayatı hem de Osmanlı-İran münasebetlerinin siyasi ve sosyal yansımaları açısından önemli bir figür haline gelmiştir. Gazeteyi yayınlamadan önce de kurduğu matbaa ile yayıncılık faaliyetlerini yürüttüğü bilinen Tahir Efendi, Ahter yayın hayatına devam ederken ve kapandıktan sonra da gazete ile aynı ismi taşıyan matbaasında yayıncılık faaliyetlerini sürdürmüştür. Ahter' in başlangıçta Kaçar Hanedanı'nın maddi desteği ile yayınlandığı ancak daha sonra II. Abdülhamid'in İslam birliği siyasetinin sözcülerinden biri haline geldiği göz önünde bulundurulduğunda, Tahir Efendi'nin şahsiyetinin ve gerek Osmanlı Devleti ile gerekse matbuat hayatındaki kişi ve kurumlarla ilişkilerinin dikkatle ele alınması gereği tebarüz etmektedir.

Ahter gazetesi üzerine yapılmış ve son zamanlarda giderek zenginleşen çalışmalar, gazetenin yayın hayatı boyunca sahibi ve mesul müdürlüğünü üstlenmiş ve zaman zaman kendi adıyla yazılar kaleme almış Muhammed Tahir Tebrizî hakkında ne yazık ki birkaç cümleyi geçmeyen oldukça sınırlı bilgiler sunmaktadır. Bu eksikliği gidermek maksadıyla hazırlanan bu makale, XIX. asır Osmanlı ve İran basın tarihi açısından önemli bir figür olan Tahir Efendi'nin öncelikle biyografisiyle ilgili temel bilgileri açığa çıkartmayı ve matbuat faaliyetlerini ortaya koymayı amaçlamaktadır. Ayrıca çoğunluğu tüccar ve sürgündeki İran meşrutiyeti yanlıları olmak üzere İstanbul'da mukim İranlılar, İstanbul'daki İran sefareti ve Osmanlı Devleti ile ilişkileri de ele alınacaktır.

\section{Muhammed Tahir Tebrizî Kimdir?}

Muhammed Tahir Tebrizînnin kimliğine dair en somut bilgi, İstanbul'da mukim İranlı bir tüccar olduğudur. Biyografisiyle ilgili doğum ve vefat tarihi de dâhil olmak üzere pek çok temel bilgiden yoksun olduğumuzu daha baştan ifade etmek gerekir. Tebrizî ve Karacadağî nisbelerinden İran'ın bu bölgesinden İstanbul'a göçtüğü anlaşılmaktadır.

Yirmili yaşlarında ticaret yapmak üzere İstanbul'a geldiği söylenmekle birlikte ne bu bilginin açık bir dayanağı vardır ne de bu göçün tam olarak ne zaman gerçekleştiği bilinmektedir. ${ }^{2}$ 1279/1862 senesinde matbaa açmak için ilk ruhsatı-

2 Tanya Lawrence, tezinde yirmili yaşların başında İstanbul'a geldiğini ve Meşrutiyet’ten bir süre sonra gerçekleşen vefatına kadar İstanbul'da yaşadığını Browne’a dayanarak ifade etse de Browne'da sadece "hala hayatta olduğu" ifadesi yer almaktadır. Bkz. Tanya E. Lawrence, Akhtar: 
nı aldığını ifade etmesinden, en geç 1860ların başında İstanbul'a geldiği düşünülebilir. ${ }^{3}$ Aynı şekilde 1912 yılı Haziran ayı itibariyle hayatta olduğu bilinmekle ${ }^{4}$ birlikte ne zaman vefat ettiği de meçhuldür. Uzun süre pek çok hemşerisinin de tercih ettiği üzere Beyazıt'ta oturduğunu bildiğimiz Muhammed Tahir, daha sonra Kuzguncuk'a taşınmıştır. ${ }^{5}$ Validehan'da bir matbaası ve Hakkaklar Çarşısında bir kitapçı dükkânı vardır. ${ }^{6}$

Muhammed Tahir'in tüccarlığın dışında Encümen-1 Teftiş ve Muayene ${ }^{7}$ azalığı yaptığı arşiv belgelerinden ve salnâmelerden anlaşılmaktadır. Hicri 1317 tarihli salnâmede ilk defa encümen azaları arasında ismi zikredilen Tahir Efendi'nin, salnâmelerin bir önceki senenin bilgilerini sunduğu göz önünde bulundurulduğunda 1316/1898-99 yılı içerisinde bu göreve atandı̆̆ı

A Persian Language Newspaper Published in Istanbul and The Iranian Community of The Ottoman Empire in The Late Nineteenth Century, İstanbul 2015, s. 33.

3 BOA, DH.MDK 220/88 (28 Z 1309/ 24 Temmuz 1892).

4 Edward G. Browne, The Press and Poetry of Modern Persia, Cambrigde 1914, s. 2, 36. Ayrica bkz. Rahim Reis Niya, İan ve Osmanî der Âsitane-i Karn-i Bistom, Tahran 1328, I, 425. Rıza Kurtuluş, hazırladığı doktora tezinde Muhammed Tahir'in vefat tarihini yanlış bir şekilde ve kaynak göstermeksizin 1907 olarak verir. Nasıruddin Pervin de İran basın tarihiyle ilgili kitabının Ahter'le ilgili bölümünde Muhammed Tahir'i tanıtırken 21 Zilkade 1325/26 Aralık 1907 tarihinde İstanbul'da vefat ettiğini yine kaynak göstermeden yazmıştır. Bkz. Rıza Kurtuluş, 1906-1911 İran Meşrutiyet Hareketinde Osmanl Etkisi, Marmara Üniversitesi Ortadoğu Araştırmaları Enstitüsü, Yayınlanmamış Doktora Tezi, İstanbul 2010, s. 182; Nasıruddin Pervin, Tarih-i Ruznâme-Nigârî-i İraniyân ve Diger Parsi-Nevisiyan, Tahran 1377, I, 250 .

5 Han Efşar, sefernâmesinde Muhammed Tahir’i 7 Şevval 1299/ 22 Ağustos 1882 Salı günü Beyazıt'taki evinde ziyaret ettiğini kaydetmiştir. Bkz. Resul Caferiyan (ed.), Sefernâmehâ-yi Hacc-ı Kâcârî, Tahran 2011, IV, 516-517. BOA, DH.MDK 154/90 (25 C 1327/14 Temmuz 1909).

6 BOA, DH.MDK 154/90 (25 C 1327/14 Temmuz 1909). Han Efşar, sefernâmesinde hem Validehan'daki matbaayı hem de "Beyazıt yangın kulesine yakın" diyerek yerini tarif ettiği kitapçı dükkânını ziyaretini anlatır. Bkz. Caferiyan, Sefernâmehâ, IV, 521, 532-533.

7 1298/1880 yllında teşkil edilen Maarif Nezareti’ndeki bu birim, gazeteler de dâhil alelumum neşriyatı ve yurt dışında basılıp gümrüklerle postanelere gelen her dilden yayını tetkik etmekle görevlidir. Maarif Nezareti’ndeki bu birime 1315/1897 yılında kurulan Tetkik-i Müellefât Komisyonu ile 1321/1903 yılında kurulan Kütüb-i Diniyye ve Şer'iyye Tetkik Heyeti de ilave edilmiştir. Başlangıçta bir reis ve altı azadan teşekkül eden bu encümenin zamanla aza sayısında artışlar olmuştur. Bkz. Salnâme-i Nezaret-i Maarif-i Umumiyye, 1318/1900, s. 527; Ali Birinci, "Osmanlı Devleti'nde Matbuat ve Neşriyat Yasakları Tarihine Medhal", TALIDD, VII, 4/2006, s. 303-305. 
anlaşılmaktadır. ${ }^{8}$ İsmi dışında herhangi bir rütbe ya da nişana sahip olduğunu gösterir kayıt yoktur. 1318, 1319 ve son olarak 1320 tarihli salnâmelerde de aynı kayıt tekrarlanmış, başka bir açıklama ilave edilmemiştir. ${ }^{9} 1317$ tarihli Maarif Nezareti Salnâmesinde ise 2. dereceden Mecidi nişanını haiz olduğu görülmektedir. ${ }^{10} 1318$ ve 1319 tarihli salnâmelerde ise rütbe-i saniyeyi haiz olduğu kaydedilmiştir. ${ }^{11}$

Tahir Efendi'nin encümen azalığını söz konusu eden ulaşabildiğimiz en erken tarihli arşiv belgesi ise 17 Rabiulevvel 1319/21 Haziran 1317 (4 Temmuz 1901) tarihli Sadrazam imzalı bir belgedir. Belgeye göre bu memuriyeti esnasında izinsiz takvim bastığı için hakkında 23 Zilhicce 1319/2 Nisan 1902 tarihinde bir tutanak düzenlenerek Adliye Nezareti'ne gönderilmiş ve mahkemeye verilmiştir. ${ }^{12}$ Başka bir belgede ise Encümen-i Teftiş ve Muayene azalığı sebebiyle memur olarak matbaacılık mesleğine devam etmesi mümkün olmadığı için kapatılmış olan matbaasının aletlerinin satış bedeli tespit edilmektedir. ${ }^{13}$ Söz konusu belgenin tarihi 3 Cemaziyelahir 1321/27 Ağustos 1903 olmakla birlikte salnâmelerden Tahir Efendi’nin encümendeki görevinin, 1320 yılı bitmeden (Mart 1903) sona erdiği anlaşılmaktadır. ${ }^{14}$

8 Salnâme-i Devlet-i Aliyye-i Osmaniyye, 1317/1899, s. 300.

9 Salnâme-i Devlet-i Aliyye-i Osmaniyye, 1318, s. 336; Sâlname-i Devlet-i Aliyye-i Osmaniyye, 1319, s. 374; Salnâme-i Devlet-i Aliyye-i Osmaniyye, 1320, s. 388-389.

10 Salnâme-i Nezaret-i Maarif-i Umumiyye, 1317/1899, s. 520.

11 Salnâme-i Nezaret-i Maarif-i Umumiyye, 1318/1900, s. 528; 1319/1901, s. 35.

12 BOA, MF.TTD 52/91 (19 C 1319/3 Ekim 1901). Yine bir adli soruşturmaya muhatap olan Tahir'in yargılanmasına müsaade edilmesi için Adliye ve Maarif Nezaretleri ile Sadaret arasında uzun yazışmalar olmuştur. 7 Zilhicce 1319/17 Mart 1902 tarihli bu belgeye göre Tahir, Zaptiye Müşiri müteveffa Kerim Paşa’nın kerimesi Saliha Hanım’ın sahilhanesinin bazı mahallerini kasten yıkmış ve tahrip etmiştir. Üsküdar Bidayet mahkemesinde görülen davada Tahir'in yargılanması için memuru olduğu nezaretten izin talep edilmektedir. Ancak Maarif Nezareti, İran tebasından olan Tahir'in memuriyetinin sadaretten gelen irade ile tahakkuk ettiğini belirterek yargılanması için de yine oradan müsaade istenmesi gerektiği şeklinde cevap vermiştir. Neticede Sadaret'ten de gerekli izin çıkmış olmakla birlikte mahkemenin sonucuna dair bir bilgi verilmemiştir. Belge için bkz. BOA, MF.MKT 615/22 (7 Z 1319/17 Mart 1902). 11 Rabiülevvel 1320/18 Haziran 1902 tarihinde hala encümen-i teftiş azası olduğunu gösterir başka belge için bkz. BOA, MF.MKT 627/52 (16 S 1320/25 Mayıs 1902).

13 BOA, ŞD 218/60 (15 Ş 1321/6 Kasım 1903).

14 Tahir Efendi'yi, görevinin ayrıntılarına girmeden "İran tebasından olup Maarif nezaretinde müstahdem” şeklinde tavsif eden Şaban 1320 tarihli belgeler de bu savı desteklemektedir. Bkz. 
Tahir Efendi'nin meşrutiyetin yeniden ilanının ardından Maarif Nezareti'nde ikinci defa görev aldığı anlaşılmaktadır. Salnâmelerde herhangi bir izine rastlamadığımız bu görev, verdiği bir istida dolayısıyla kayıtlara geçmiştir. 11 Mayıs 1325/24 Mayıs 1909 tarihli istidasını, "Kuzguncuk'ta hanesinde mukim teba-yı Devlet-i İraniye'den ve Meclis-i Maarif azasından Muhammed Tahir” şeklinde imzalamıştır. ${ }^{15}$ Ancak bu görevinin ayrıntılarına dair başka herhangi bir bilgiye ulaşılamamıştır.

Mirza Muhammed Hüseyin Ferahanî, seyahatnâmesinde Safer 1303/Kasım 1885 tarihinde Validehan'da Ahter' in bürosunda ziyaret ettiği Tahir Efendi'yi şu şekilde tanıtır: "Tebrizli ve İran tebasından Mirza Tahir; faziletli, sakin, olgun, mülayim, saf ve sade bir kişi. Yıllar önce İstanbul'a gelmiş ve buraya yerleşmiş. Önceleri ticaretle meşgulmüş. Hâlihazırda da maişetini sağladığı bir birikimi var.”16

Muhammed Tahir'in, neşrettiği gazetede aynı zamanda yazılar kaleme aldığı bilinmektedir. Ancak bunun dişında bir telif çalışması yoktur. Niya, Tahirülmevlevînnin (Mehmed Tahir) kaleme aldığı Dest-âvîz-i Fârsî-hânân (1325) ve Âmuzgâr-ı Fârsî̀ (I-II, 1324) isimli Fars diliyle ilgili kitapları Muhammed Tahir' in kaleme aldığını dile getirmiştir. Ancak isim benzerliğinden kaynaklanan bir hata olduğu açıktır. Zira bunları ya da başka eserleri kaleme aldığına dair herhangi bir kayıt yoktur. ${ }^{17}$

Muhammed Tahir'in, İstanbul'da mukim İranlılarla yakın bir münasebet içinde olduğu ve kısa zamanda buradaki topluluğun önemli bir üyesi haline geldiği anlaşılmaktadır. Aynı şekilde İstanbul'a kısa ya da uzun süreli olarak yolu düşen İranlılarla da yakın münasebetler kurmuştur. Zorunlu ya da gönüllü sürgündeki siyasi ve entelektüel şahsiyetlerle ayrıntılarına daha sonra değinileceği üzere gazetesinde yazılarını yayınlamak ya da matbaasında kitaplarını basmak gibi teşrik-i mesaileri olmuştur. Ayrıca özellikle İstanbul güzergâhını kullanan İranlı hacılara da İstanbul'da bulundukları müddet boyunca rehberlik ve mihmandarlık etmiştir. ${ }^{18}$ Bu hacıların bir kısmı seyahatnamelerinde Muhammed Tahir'den bah-

BOA, DH.MDK 248/39 (6 Ş 1320/8 Kasım 1902); BOA, DH.MDK 248/63 (11 Ş 1320/11 Kasım 1902).

15 BOA, DH.MDK 154/90 (25 C 1327/14 Temmuz 1909).

16 Caferiyan, Sefernâmehâ, V, 265.

17 Niya, Iran ve Osmanî, I, 425.

18 İstanbul yolunu kullanan İran bölgesinden hacılar için bkz. Güllü Yıldız, "İranlı Hacıların Gözüyle İstanbul'u Temâşâ”, Marmara Üniversitesi İlâhiyat Fakültesi Dergisi, sy. 51, Aralık 2016, s. $135-160$. 
setmişler ve hakkındaki sınırlı bilgiyi bir nebze olsun çoğaltmışlardır. En mühimi şahsi intibalarıyla Muhammed Tahir'in insani yönünü müşahhas hale getirme noktasındaki katkılarıdır. Bu hacıların başında 1299/1882 yılında İstanbul'da kendisiyle tanışan Han Efşar Rûmî gelir. ${ }^{19}$ "Makul biri” olarak nitelendirdiği ${ }^{20}$ Muhammed Tahir ile İstanbul'da kaldığı kırk beş günlük süre boyunca neredeyse her gün görüştükleri anlaşılmaktadır. ${ }^{21}$ Han Efşar'a rehberlik edip İstanbul'un pek çok yerini gezdiren Tahir, onu İstanbul'un seyirlik mekânlarında dolaştırdığı gibi Üsküdar ve Beyoğlu’ndaki tiyatrolara, gazinolara da götürmüştür. ${ }^{22}$ Alışverişlerinde ona yardımcı olmuştur. ${ }^{23}$ Hatta Han Efşar, İstanbul'da satın aldığı bazı eşyaları sandıklayıp dönüşte İstanbul'dan giderse kendi götürmek yoksa Tahran'a gönderilmek üzere Tahir’in yanına emanet bırakmıştır. ${ }^{24}$

Muhammed Tahir Tebrizî, kurduğu matbaa ve çıkardığı gazete Abter ile o kadar özdeşleşmiştir ki Ahter bir tür lakab ya da soy ismi işlevi görmüştür. Hac yolculuğu esnasında İstanbul'a uğrayan Naibüssadr, seyahatnamesinde Muhammed Tahir'den Ahter Efendi diye bahsetmiştir. ${ }^{25}$ Aynı şekilde çocuklarından bahsedilirken örneğin büyük oğlu için "Hüseyin Ahter" denmektedir. ${ }^{26}$

Hacı Abdullah Emir Nizam Karagözlü ${ }^{27}$ de 28 Şevval 1319/7 Şubat 1902'de İstanbul'da katıldığı bir baloda tanıştığı Muhammed Tahir'i "bir gazete sahibi,

19 Urumiyeli, Kaçar eşrafından olan Mirza Abdülhüseyin Han Efşar Rûmî, 1882 yılı Temmuz ayında çıktı̆̆ı, dokuz ay süren ve Tahran-Kazvin- Reşt-Enzeli-Bakü-Tiflis-Batum-İstanbulCidde-Mekke-Medine-cebel yoluyla Semave- Fırat yoluyla Necef- Kerbela- Kazımeyn-SamerraBağdat-Ba'kube-Kasr-1 Şirin-Kirmanşah-Kum-Tahran güzergâhını takip ettiği hac yolculuğunu günlük tarzında kaleme aldığı Sefernâme-i Mekke-i Muazzama isimli sefernâmesinde ayrıntılarıyla anlatmıştır. Bu yolculuğu dünyadaki yenilikleri görmek için bir fırsat ittihaz ettiği anlaşılan Han Efşar, 29 Ramazan 1299/14 Ağustos 1882 tarihinde vardığı ve kırk beş gün kaldığı İstanbul'da da kendisine "basiret" kazandıracağı düşüncesiyle dur durak bilmeden gezmiştir. Bu gezilerindeki rehberi ve ahbabı ise Muhammed Tahir'dir. Han Efşar ve sefernâmesi hakkında bilgi için bkz. Caferiyan, Sefernâmehâ, IV, 441-448.

20 Caferiyan, Sefernâmehâ, IV, 511.

21 Caferiyan, Sefernâmehâ, IV, 511-543.

22 Caferiyan, Sefernâmehâ, IV, 522, 524, 529-530, 536-537, 542.

23 Caferiyan, Sefernâmehâ, IV, 523-524.

24 Caferiyan, Sefernâmehâ, IV, 542.

25 Caferiyan, Sefernâmehâ, V, 386.

26 Niya, İran ve Osmanî, I, 83. Gazetenin uzun bir süre başyazarlığını yapmış Mirza Mehdi Han Tebrizî de Ahter isminin bir parçası haline gelmiş ve kendisine Mirza Mehdi Ahter denmiştir. Bkz. Pervin, Tarih-i Ruznâme, I, 250.

27 Hacı Abdullah Emir Nizam Karagözlü de İstanbul üzerinden hacca giden ve bu yolculuğuna dair Sefernâme-i Mekke-i Muazzama ismiyle bir eser kaleme alan İranlı hacılardandır. 15 Şevval 
çok genç ve hoş biri” olarak tarif etmiştir. ${ }^{28}$ Muhammed Ma’sum Naibüssadr Şirazî, ${ }^{29}$ Ahter' in sahibi olarak tanıştığı ve görüştüğü Mirza Tahir' in İranlılara karş1 çok muhabbeti olduğunu ve devlet için yararlık gösterdiğini dile getirmiştir. ${ }^{30}$

Hizmetlerinden dolayı 1314 yılının başlarında (1896), yani Muzafferüddin Şah döneminin başlangıcından üç ay sonra Muzafferüddin Şah tarafından kendisine ikinci dereceden Şir-i Hurşid nişanı verilmiştir. ${ }^{31}$

Abter' in yazarlarından Mirza Ağa Han Kirmanî de Muhammed Tahir'i yakından tanıyanlardandır. Muhtemelen 1311 yılının Kurban bayramında Malkum'a yazdığı mektupta ondan "üçkâğıtçı ve hilekâr biri” olarak bahsetmiştir. Onunla ilişkisi hakkında ise "ara sıra Ağa Muhammed Tahir'in hırsızlıkları, gizli kapaklı işleri matbuatta patlıyor. Ben onun vicdana sığmayan işler yaptığını gördüm ve sonunda onu terk ettim. $\mathrm{O}$ da benim bir miktar paramı yedi. Daha sonra da Sefaret'in ona karşı düşmanlığı su yüzüne çıktı. Artık onunla açı ve gizli hiçbir bağım kalmadı" demiştir. ${ }^{32}$ Ancak Kirmanînnin bu ifadelerini, tamamen yollarını ayırma şeklinde sonuçlanan anlaşmazlıklarını göz önünde bulundurarak değerlendirmek gerekir. ${ }^{33}$

1319/25 Ocak 1902'de Reşt'ten başlayan yolculuğunda Enzeli-Tiflis, Batum hattından İstanbul'a gelen ve gemiyle Cidde’ye devam eden Karagözlü̉ nün yol arkadaşlarından biri, İran meşrutiyet ihtilali karşıtlarının en önemli isimlerinden Şeyh Fazlullah Nuri'dir (1843-1909) ve bu sebeple uğradıkları her şehirde özel olarak karşılanmış ve ağırlanmışlardır. 26 Şevval/5 Şubat 1902'de vardıkları İstanbul'da da sultanın huzuruna kabul edilecek kadar önemsenmişlerdir. Bkz. Caferiyan, Sefernâmehâ, VII, 159.

28 Caferiyan, Sefernâmehâ, VII, 195. Hacı Muhammed Ali Pirzâde de İstanbul'dan ayrilırken gemiye gelip kendilerini uğurlayanlar arasında Ahter'in müdürü Ağa Muhammed Tahir'den bahsetmiştir. Bkz. Sefernâme-i Hacı Pirzâde, haz. Ferman Fermaiyan, Tahran 1343, II, 124.

29 Muhammed Ma'sum Ali Şah Naibüssadr (1270-1344); Atabat şehirlerinde aldığı dini eğitimin ardından Tahran'da eğitimine devam eden Muhammed Ma‘sum, tasavvufla ilgili çalışmalar yapmıştır. Bir rüya üzerine hacca gitmeye karar vermiş ve 3 Şevval 1305/ 13 Haziran 1888'de yola çıkmıştır. 27 Şevval 1305/7 Temmuz 1888'de vardığı İstanbul'daki durumdan genel olarak memnun kalmamıştır. Bkz. Caferiyan, Sefernâmehâ, V, 375.

30 Caferiyan, Sefernâmehâ, V, 379.

31 Pervin, Tarih-i Ruzname, II, 458. Mirza Mehdi'ye de üçüncü dereceden nişan verilmiştir. Ahter'de bunun haberi yayınlanmıştır. Bkz. Ahter, XXXII/8, 24 Safer 1314.

32 Niya, İran ve Osmanî, I, 421.

33 Kirmânî, özellikle Tahir’in damadından dolayı yaşadıkları anlaşmazlıklarından, 1308 yılında Malkum’a yazığı mektubunda bahsetmiş ve Ahter gazetesinin yayınının durdurulması haberini verirken şöyle demiştir: "bu günlerde o menfur, canavar, hayvanın (Mirza Hüseyin Şerif, damadı) kötülükleri onu (Muhammad Tahir'i) da etkiledi”. Bkz. Niya, İran ve Osmanî, I, 421-422. 
Muhammed Tahir Tebrizîn nin ailesine baktığımızda tespit edebildiğimiz dört oğlu ve bir kızı vardır. Ayrıca çekirdek ailesi dışında kayıtlara yansıdığı kadarıyla İstanbul'da bir kardeşinin daha yaşadığı bilinmektedir ancak birlikte mi yoksa farklı zamanlarda mı İstanbul'a geldikleri ya da burada başka akrabaları olup olmadığına dair açıklayıcı bir bilgiye rastlanmamaktadır.

Oğullarından Ali ve Kemal hakkındaki ilk bilgilerimiz, 1881 yılında Mekteb-i Fünûn-ı Mülkiye'de tahsil görmeleri için başvuru yapıldığına dair bir belgeye dayanmaktadır. Belgeye göre o tarihte on yedi ve on dört yaşlarında olan Ali ve Kemal Efendi, yaşlarının uygun olmaması ve İran tebasından olmaları sebebiyle Mülkiye'ye kabul edilmemişlerdir. ${ }^{34}$ Dolayısıyla sırasıyla 1865 ve 1868 yıllarında doğmuş olsa gerekler. Bunun dışında tahsil durumları ya da hayatlarının başka ayrıntılarına dair bir bilgiye sahip değiliz. Sadece yine belgelerden matbaa ve kitapçılık işlerinde babalarıyla birlikte çalıştıkları bilinmektedir. Hakkaklar çarşısı 19 numarada yer alan Ahter Kütüphanesi'nin idaresinin bir dönem Ali Efendi'nin uhdesinde olduğu anlaşılmaktadır. ${ }^{35}$ Kemal de hem kitapçıda ${ }^{36}$ hem de babasının Validehan'daki Ahter Matbaası'nda çalışmaktadır. ${ }^{37}$

Diğer oğullarından Hüseyin, ilk eğitimini İranlıların İstanbul'daki okulunda tamamlamıştır. Öğrencilik yıllarında babasının İranlı topluluk içinde prestiji sayesinde gerek okul müsamerelerinde gerekse İran Sefaretinin düzenlediği Şah’ın doğum günü ya da nevruz kutlamaları gibi çeşitli merasimlerde okulu temsilen boy gösterdiği anlaşılmaktadır. Yine böyle bir münasebetle Ahter'de yayınlanan

Kirmânînin bir müddettir Ahter'den parasını alamadığı; Malkum’a yazdığı 1310 yılı Ramazan bayramı (Nisan 1893) tarihli mektuptan anlaşılmaktadır. Bkz. Pervin, Tarih-i Ruznâme, I, 275. Malkum Han ile tanışma ve görüşme şansını yakalayamayan Mirza Ağa Han Kirmânînin İstanbul'dan yazdığı bu mektuplar, Malkum Han'ın diğer mektupları ve şahsi evraklarının da bulunduğu Fransa Ulusal Kütüphanesi Arşivi'ndedir. Orijinallerine ulaşma imkânı henüz elde edilemediği için çeşitli çalışmalarda yayınlanmış olanlardan istifade edilmiştir. 1924 yılında Malkum'un eşi tarafından bağışlanan mektupların orijinalleri için bkz. E. Blochet, Catalogue des Manuscrits Persans, IV, Paris 1934, s. 284-291.

34 BOA, MF.MKT 73/79(9 S 1299/31 Aralık 1881); BOA, MF.MKT 74/11 (23 S 1299/14 Ocak 1882).

35 Ali Efendi’nin kitapçı dükkânını idare ettiği dönemin, arşiv belgelerinin verdiği tarihlere dayanarak en azından 19 Rabiulevvel 1315-11 Rabiulevvel 1320/18 Ağustos 1897-16 Ağustos 1902 olduğunu söylemek mümkündür. Bkz. BOA, MF.TTD 37/127 (19 Ra 1315/18 Ağustos 1897); BOA, MF.MKT 627/52 (16 S 1320/25 Mays 1902).

36 BOA, MF.MKT 323/55 (3 M 1314/14 Haziran 1896).

37 BOA, MF.TTD 35/35 (12 Ş 1314/16 Ocak 1897). 
bir haberde Eylül 1891 tarihinde on üç yaşında olduğu belirtilmektedir. ${ }^{38} \mathrm{Bu}$ bilgiye dayanarak Hüseyin'in 1878'de İstanbul'da doğduğu rahatlıkla söylenebilir.

Hüseyin, ilk eğitiminin ardından askerî okula devam etmiştir. ${ }^{39}$ Ahter gazetesinin son yıllarında Fransızca mütercimi olarak yer aldığı da görülen ${ }^{40}$ Hüseyin' in hayatı, askerî eğitiminden dolayı tüccar ve yayıncı babasından çok farklı bir seyir göstermiştir. Askerî okulda Alman General Von der Goltz Paşa’nın gözde talebelerinden biri olan Hüseyin, Muzafferüddin Şah'ın İstanbul'u ziyaretinde (1318/1900), üsteğmen rütbesindedir ve şahın isteğiyle İran’a gitmiştir. O dönem iyi durumda olmayan ordunun yeni bir nizama kavuşması için askerleri eğitmekle görevlendirilen Hüseyin, kendisini Alman imparatoru II. Wilhem'e benzettiği, görüntüsünden dolayı bakışları üzerinde topladığı ve gür ve mühib bir sesle sürekli emirler yağdırdığ için askerler arasında alay konusu olmuş ve bu görevde başarısız olacağını anlayarak istifa etmiştir. İran'da yaşadığı bu hayal kırıklığının ardından Hollanda’ya gitmiş ve orada zengin bir kadınla evlenerek bir süre rahat bir hayat sürmüştür. Birinci Dünya Savaşı esnasında Almanlar Belçika’yı işgal ettiklerinde Almanların Belçika naibi olan Mareşal Von der Goltz’un isteğiyle Alman Şark İdare’sinde çalışmaya başlamıştır. Verilen görev dolayısıyla İran, Bağdat, Hindistan gibi bölgeleri dolaşıp bir süre İran-Osmanlı sınır hattında yaşadıktan sonra Halep’te şüpheli bir şekilde infaz edilmiştir. ${ }^{41}$

38 “Debistan-ı İraniyan'ın çocuklarından; gazetemizin imtiyaz sahibi Ağa Muhammed Tahir’in on üç yaşındaki oğlu Hüseyin Bey (6 Safer 1309/11 Eylül 1891) Perşembe günü Nâsırüddin Şah'ın doğum günü münasebetiyle sefarette icra edilen törende şiir okudu ve sefir, Keşmir yününden bir şal hediye ederek kendisini taltif etti.” Bkz. Ahter, XVIII/1, (11 Safer 1309/15 Eylül 1891), s. 4. Benzer bir başka haberde "Sefarette, İran Sefiri Mirza Esedullah Han Nâzımüddevle’nin huzurunda düzenlenen Nevruz merasiminde, Ahter'in müdürü ve imtiyaz sahibi Ağa Muhammed Tahir'in oğlu ve Debistan'ın beşinci sınıfındaki istidatlı talebelerinden Hüseyin Bey, Sefir-i kebirin fotoğrafına çok benzeyen bir resmini takdim etti. Takdir ve aferin aldı." Bkz. Ahter, XVIII/28 (22 Şaban 1309/23 Mart 1892), s. 218. Ahter ile İranlılar'ın okulu arasındaki ilişki Tahir' in oğlu ile sınırlı değildir. Ahter' in yazarlarından Mirza Mehdi Tebrizî, Mirza Ağa Han Kirmânî ve Mirza Habib Isfahanî de bu okulda öğretmenlik yapmışlardır. Bkz. Lawrence, Akhtar: A Persian Language Newspaper, s. 34.

39 Kuleli'de okuyan İranlı öğrencileri isim isim zikreden ve okuldaki durumları ve okudukları dersler gibi ayrıntılara yer veren Pirzâde, Hüseyin Ahter’i bu isimler arasında anmamıştır. Ancak bunun sebebi zikrettiği talebelerin İran'dan askeri eğitim için gelen kişiler olmalarıdır. Tahir'in oğlu İstanbul'da doğmuş ve burada yetişmiş olmasıyla diğerlerinden ayrılır. Bkz. Sefernâme-i Pirzâde, II, 112-113.

40 Pervin, Tarih-i Ruznâme, I, 251; II, 458.

41 Niya, İran ve Osmanî, I, 84. 
Diğer oğlu Mirza Hasan Celaleddin'in ise Berlin'de hukuk eğitimi aldığı bilinmektedir. Muhtemelen kardeşi Hüseyin gibi ilk eğitimini İranlıların okulunda aldıktan sonra eğitimini sürdürmek üzere Almanya’ya gitmiştir. Hasan Celaleddin'in ismine ilk olarak Nâsıruddin Şah’ın öldürülmesinden (3 Zilkade 1313 / 16 Nisan 1896) sonra Ahter'de yayınlanan yazısında rastlanmaktadır. Merhum şahı ve yerine gelen Muzafferüddin Şah'ı (v. 1324/1907) öven yedi sütunluk bu yazı, Berlin'de kaleme alınmış ve yayınlanması için gönderilmiştir. ${ }^{42}$

Muzafferüddin Şah'ın ilk Avrupa gezisi esnasında (27 Rabiulevvel 1318/25 Temmuz 1900 'de) gördüğü kişilerden biri de Hasan Celaleddin'dir. ${ }^{43}$ Yine bu yolculuğunda Budapeşte'de iken hem Muhammed Tahir'e hem de iki oğluna ihsanlarda bulunmuş, Tahir'e bir elmas yüzük hediye ederken Berlin'deki Hasan'a 20 tümen maaş bağlanmasını ve İstanbul'daki Hüseyin'e 1000 Frank verilmesini ve İran'da ordusunda hizmet etmek üzere görevlendirilmesini emretmiştir. ${ }^{44}$

Hasan Celaleddin ismine Ahter Matbaasında basılan Musavver Terâcim-i Ahvâl-i Meşâhbir-i Ricâlserisinden çıan üç kitap ile Fennî Eğlenceler' in mütercimi ve Öksüz isimli eserin müellifi olarak rastlanmaktadır. 1308/1891 yılında yayınlanan bu kitapları Tahir'in oğlu Hasan Celaleddin'in yazmış ve çevirmiş olması kuvvetle muhtemeledir. ${ }^{45}$

Kızı olduğu ise kaynaklarda damadı Mirza Hüseyin Şerif’ten bahsedildiği için bilinmektedir. Kızı hakkında başka bir bilgi olmamakla birlikte özellikle Ahter'de birlikte çalıştığı için damadı hakkında çoğunlukla olumsuz bazı bilgi ve intibalara yer verilmiştir. Aslen Kâşânlı Molla Ahmed Fazıl Neraki’nin torunlarından olan Mirza Hüseyin Şerif, gençliğinde doğduğu yerden ayrılıp bir süre Atabat şehirlerinde yaşamış ve ardından Hindistan’a gitmiştir. Yıllarca

42 Abter, XXII/43 (20 Zilhicce 1313/2 Haziran 1896), s. 674-677. Ayrica bkz. Niya, Iran ve Osmanî, I, 424.

43 Muzafferüddin Şah'in, Sefernâme-i Frengistan: Sefer-i Evvelinden naklen Niya, Iran ve Osmanî, I, 929.

44 Perveriş, I/22 (26 Receb 1318/22 Kasım 1900), s. 424'den nakleden Niya, İran ve Osman̂̂, I, 929. 45 Musavver Terâcim-i Ahvâl-i Meşâhir-i Ricâl: David Livingston, çeviren: Hasan Celaleddin, İstanbul 1308/1891, Ahter Matbaası, 31 s.; Musavver Terâcim-i Ahvâl-i Meşâhir-i Ricâl: James Cook, Çeviren: Hasan Celaleddin, İstanbul 1308/1891, Ahter Matbaası, 28 s.; Musavver Terâcim-i Ahvâl-i Meşâhir-i Ricâl: Jean-François de La Pérouse, Çeviren: Hasan Celaleddin, İstanbul 1308/1891, Ahter Matbaası, 30 s; Tom Tit [Arthur Good], Fennî Eğlenceler, çev. Hasan Celaleddin, İstanbul 1308/1891, Ahmet Matbaası, 36 s.; Öksüz, Hasan Celaleddin, İstanbul 1308/1891, Ahter Matbaası, s. 46. 
orada İngiltere'nin siyasi idaresinde çalıştıktan sonra 1300/1882-1883'ten sonraki bir tarihte Avrupa'ya gitmiştir. Avrupa'daki gezisinin ardından İstanbul'a gelerek Muhammed Tahir' in kızıyla evlenmiş ve buraya yerleşmiştir. O da kayın pederi gibi bir yandan ticaretle meşgul olurken bir yandan da Ahter'in işleriyle ilgilenmiştir. $^{46}$

1307 Cemaziyelahir/Şubat 1890'da yapılan dügüne başta sefir Muinülmülk, bütün sefaret mensupları ve İranlı muteber tüccarlardan pek çoğu katılmıştır. ${ }^{47}$ Bâbilerden olan Mirza Şerif Hüseyin, ${ }^{48} 1311 / 1893$ yılına kadar İstanbul'da yaşadıktan sonra hastalığı nedeniyle hava değişimi için Mısır’a gitmiştir. Geride hatırı sayılır ve tartışmalara konu olan bir servet bırakarak orada vefat etmiştir. ${ }^{49}$ Mısır'da vârissiz vefat etmiş olması Muhammed Tahir'in kızından çocuğu olmadığını ve Mısır’a giderken karısından ayrıldığını düşündürmektedir. ${ }^{50}$ Ancak vefatının ardından Muhammed Tahir tarafından hakkında övgü dolu bir vefat yazısı yazılmış olması, aralarının Mısır'a gidişiyle bozulmadığını gösterir. ${ }^{51}$

Muhammed Tahir'in İstanbul'da yaşayan kardeşiyle ilgili bilgiye ise Han Efşar'ın sefernâmesinde rastlanmaktadır. Buna göre Muhammed Tahir'in Üsküdar'da mukim Mahmud isminde bir kardeşi vardır. ${ }^{52}$

46 Abter, XXII/22 (21 Receb 1313/7 Ocak 1896), s. 341; Niya, Iran ve Osmanî, I, 537, 540.

47 Ahter, XVI/24 (19 Cemaziyelahir 1307/10 Şubat 1890), s. 195; Niya, İran ve Osmanî, I, 538-539.

48 Ahter'in yazarlarından olup özellikle Mirza Hüseyin Şerif'in gazeteye gelişinden sonra hem Mirza Hüseyin Şerif'le hem de Muhammed Tahir ile arası açılan ve gazeteden ayrılmak durumunda kalan Mirza Ağa Han Kirmânî 1308 yılının ortalarında (1891) Malkum’a yazdığı mektubunda Mirza Hüseyin Şerif'ten bahsederken babası Muhammed Cafer Neraki’nin Bâbiyye'nin ileri gelenlerinden olduğunu ifade etmiştir. Mektup için bkz. Niya, İran ve Osmanî, I, 538-539. Ayrıca bkz. Homa Nategh, "Mirzâ Âqâ Khân, Sayyed Jamâl al-Din et Malkom Khân à Istanbul (18601897)", Les Iraniens d'Istanbul, ed. Thierry Zarcone-F. Zarinebaf-Shahr, Istanbul-Teheran, 1993, s. 48.

49 Niya, Iran ve Osmanî, I, 539.

50 Niya, İran ve Osmanî, I, 540.

51 Abter, XXII/22 (21 Receb 1313/7 Ocak 1896), s. 341; Niya, İran ve Osmanî, I, 539.

52 İranlı hacılardan Han Efşar, Muhammed Tahir'le 11 Şevval (1299/26 ağustos 1882) günü gezmek için Üsküdar'a giderler. Önce Bağlarbaşı’ndaki tiyatroda bir oyun izlerler. Ardından Çamlıca’ya çıkıp muğanniler eşliğinde zevk ü sefa ederler. Vapur saatini kaçırdıkları için geceyi Üsküdar’da geçirmek durumunda kalırlar. O günlerde Tahir'in evi Beyazıt'tadır. Han Ef̧̧ar ise Bâbıâlî yakınlarında bir misafirhane olan Ruy Hotel'de kalmaktadır. Tahir, çareyi Üsküdar'da mukim kardeşi Mahmud Ağa’ya misafir olmakta bulur. O gece Selamsız'da çıkan yangını izlediklerine göre kardeşinin evi o civarda olmalıdır. Bkz. Caferiyan, Sefernâmehâ, IV, 522-523. 


\section{Kitapçı Tahir Efendi}

En yalın haliyle bir tüccar olarak tanımladığımız Muhammed Tahir Tebrizînnin, İstanbul'a göç ettikten sonra ne türden bir ticari faaliyet içerisinde olduğu bilinmemektedir. ${ }^{53}$ Ancak bir süre sonra kitapçı dükkânı açtığı ve matbaa kurarak neşir faaliyetlerine giriştiği görülmektedir. Dolayısıyla artık o "Kitapçı Tahir Efendi"dir. ${ }^{54}$

Kitapçı Tahir, kitabın hem basımı hem de satışıyla meşgul olmuştur. Matbaasında bastığı kitaplar da dâhil olmak üzere içerde ve dışarda basılan pek çok eseri kitapçı dükkânında satışa sunmak suretiyle İstanbul halkına ve İstanbul'a yolu düşen kitap meraklılarına ulaştırmıştır. Aynı zamanda Osmanlı sınırları dışına da posta yoluyla kitap göndermiştir. İdaresini, oğlu Ali ile birlikte yürüttüğü Ahter Kütüphanesi, Hakkaklar çarşısı (şimdiki Sahhaflar çarşısı) 19 numaradadır ve üzerinde "İran ve Hindistan Matbuatı" levhası bulunur. ${ }^{55}$ Tahir Efendi'yi kitapçı dükkânında ziyaret eden Han Efşar'ın "Beyazıt yangın kulesine yakın” diye tarif ettiği yer de burası olsa gerektir. ${ }^{56}$

İlk olarak 1279/1862-63'te bir matbaa ruhsatı aldığını ve bir süre Rusya tebasından $\mathrm{Hac}$ Abbas Kerimov ile ortaklık yürüttügünü söyleyen ${ }^{57}$ Tahir’in 1876'nın Ocak ayında ilk sayısı neşredilen Abter gazetesini yayınladığı Ahter Matbaası'nı kurana kadar ne türden yayın faaliyetleri içerisinde olduğunu tam olarak belirlemek mümkün değildir. Ahter Matbaası'nı kurduktan sonra oranın

53 İstanbul'da mukim İranlı tüccarların ticari faaliyetleriyle ilgili bkz. Han Melik Sasani, Payitahtın Son Yillarında Bir Sefir, çev. Hakkı Uygur, İstanbul 2006, s. 74.

54 BOA, MF.TTD 24/120 (25 R 1310/16 Kasım 1892). Han Melik Sasani’nin ifadesine göre İranlı tüccarların içinde ağırlıklı olarak halıcılardan sonra kitap satıcıları ve kâğıt imalatçıları gelmektedir. Bunların hem sayısı çok fazladır hem de aralarında çok fazla muteber ve servet sahibi tüccar bulunmaktadır. Bkz. Sasani, Payitahtın Son Yullarında, s. 75.

55 BOA, MF.MKT 627/52 (16 S 1320/25 Mayıs 1902). 1308/1890 yilında Ahter Matbaasínda basılan Macera-yı Aşk için "sahib ve naşiri; Bâbıâlî caddesinde 13 numaralı Ahter Kitabhanesi” şeklinde verilen açıklama dükkânın daha önce zikredilen adreste olduğunu göstermektedir. Hakkaklar çarşısı 19 numaralı dükkânın ise, 1901 yılında yine İranlı bir kitapçı olan Hacı Kasım tarafından kullanılmaya başlandığına dair bir not vardır. Ancak Tahir’in buradan başka bir dükkâna taşındığı bilinmemektedir. Hacı Kasım’ın dükkânı için bkz. Naşid Baylav, İlk Türk Kitapçılarından Hacı Kasım Efendi, İstanbul 1962, s. 20.

56 Caferiyan, Sefernâmehâ, IV, 532-533.

57 BOA, DH.MDK 220/88 (28 Z 1309/24 Temmuz 1892). 
idaresiyle meşgul olduğu için 1309/1892 senesinde, kurduğu ilk matbaanın idaresini ortağına devrettiği anlaşılmaktadır. ${ }^{58}$

İstanbul'da bulunan matbaaların listesinin verildiği en eski salnâmede (1294/1877) Muhammed Tahir ya da Abbas adına kayıtlı bir matbaa görünmemektedir. Ancak mezkûr listede, sahibiyle ilgili herhangi bir bilgi verilmeksizin zikredilen Validehan'da litografya baskı yapan "İran Şirketi", daha sonraki yıllarda Abbas adına kayıtlı görünen, Şirket-i Sahafiye-i İraniye’yi akla getirmektedir. ${ }^{59}$ 1316 yılı salnâmesine göre Hacı Abbas Kerim ya da namı diğer Kerimov, Litografya Türkçe baskı yapan Şirket-i Sahafiye-i İraniye Matbaasının sahibidir. 1290 yilında kurulan bu matbaa, Validehan'da bulunmaktadır. ${ }^{60}$

İlk matbaa listesinde Tahir adına herhangi bir matbaa kaydı olmaması, Hacı Abbas Kerim ile ortak kurdukları bu ilk matbaanın Şirket-i Sahafiye-i İraniye olduğu yönündeki tahmini güçlendirmektedir. Validehan'daki kaliçe tüccarlarından merhum Hacı İbrahim Halil Efendi'nin oğlu İsmail'in, babasının veresesiyle ilgili hak talebi için Şura-yı Devlet'e verdiği dilekçede, 1307/1890 yılında vefat eden babasının, yirmi beş yıldır Validehan'da kitap ve risale basımıyla iştigal eden Şirket-i Sahafiye-i İraniye'nin 23/40'lık hisse ile en büyük hissedarı olduğu ancak diğer terekesiyle birlikte bu hisseleri gösterir senetlerin de Mirza Şefi' tarafından gasp edildiğinden bahisle, 2 Muharrem 1313/25 Haziran 1895 tarihli Abter gazetesinde şirketin dağıtılacağına dair bir ilan verildiğini belirterek mağdur olmamak için Mirza Şefi'den kendisine ait şirket senetlerinin alınmasını talep etmiştir. Dilekçede Ahter'deki ilanı veren şirketin kurucusu ve müdürü olarak Tahir ve tahvildarı olarak Abbas isimlerini zikrederek, büyük hissedar olarak kendisinin görüşü olmadan böyle bir işleme girişilmesinin de hukuka aykırılığını dile getirmiştir. ${ }^{61} \mathrm{Bu}$ dilekçe ve "Müessis ve müdür-i şirket-i mezbur Muhammed Tahir"

58 BOA, DH.MDK 220/88 (28 Z 1309/24 Temmuz 1892); BOA, DH.MDK 220/91 (28 Z 1309/24

Temmuz 1892); BOA, DH.MKT 1985/65 (1 M 1310/26 Temmuz 1892). 21 Temmuz 1894 tarihinde düzenlenen ve yakın zamanda meydana gelen zelzele dolayısıyla Validehan'daki matbaanın bulunduğu kısmın yıkıldığı ve başka bir yere taşınması gerekeceği belirtilerek teftişe daha müsait bir yere taşınmasının sağlanmasını dile getiren belge, Abbas'la Tahir'in ortaklığının daha sonra da sürdüğ̈nü göstermektedir. Bkz. BOA, MF.MKT 213/31 (17 M 1312/21 Temmuz 1894).

59 Salnâme-i Devlet-i Aliyye-i Osmaniyye, 1294, s. 632.

60 Salnâme-i Nezaret-i Maarif-i Umumiyye, 1316, s. 758-759. Celaleddin Mirza’nın Nâme-i Hüsrevan isimli eserinin buradan satın alındığına dair kayıttan aynı isimde bir de kitapçı olduğu anlaşılmaktadır. Bkz. Niya, İran ve Osmanî, I, 857.

6117 Haziran 1311/29 Haziran 1895 tarihli bu dilekçe için bkz. ŞD 2970/31 (20 Temmuz 1895/27 Muharrem 1313). 
ve "tahvildar-i şirket-i mezbur Hacı Abbas İrani” imzalı "İlan-1 Şirket-i Taba'at-1 İraniye” başlıklı Ahter'deki ilan, Tahir'in 1279'da ruhsatını aldığı ve kurduğu matbaanın Şirket-i İraniye/Şirket-i Sahafiye-i İraniye olduğunu ve bu matbaada Hacı Abbas'la ortaklığının bulunduğunu ortaya koymaktadır. ${ }^{62}$ Her ne kadar Ahter kurulduktan sonra buranın idaresini Hacı Abbas'a bırakmışsa da şirketle irtibatının devam ettiği açıktır. ${ }^{63}$

Validehan'da kurduğu ve uzun bir müddet burada çalıştırdığ $1,{ }^{64}$ aynı zamanda gazetenin bürosu olarak kullandığı Ahter Matbaası'nı, gerekli ruhsatları

62 Ahter, XXII/1, 2 Muharrem 1313/25 Haziran 1895, s. 6-7. Abter'de matbaa ile ilgili başka haberler ve ilanlar da yayınlanmıştır. Örneğin, Şirket-i İraniye matbaası müdürü imzalı bir yazıda İstanbul'da mukim İranlılar hakkında olumsuz yazılar yayınlayan Mizan gazetesine cevap verilmektedir. Özellikle Validehan'da İranlı matbaaların denetlenemediği iddiasına cevaben Teftiş heyetinden Ermeni Mihail Efendi'nin yanında bir polisle geldiği, kahvesini içtikten sonra İran sefaretinden bir memur bulunmamasına rağmen matbaayı teftiş ettiği ve basılan Kur’an-1 Kerim nüshalarını gördüğü anlatılmış, Mushaf basımıyla ilgili imtiyazın kalktığı ve Meşihat’ten izin çıktığı vurgulanarak kanuna mugayir bir iş yapılmadığı dile getirilmiştir. Bkz. Ahter, XV/1, 1306, s. 4-5; Ayrica bkz. Niya, İran ve Osmanî, I, 816-817.

63 Bir başka İranlı kitapçı Hacı Hüseyin de sonraki yıllarda bir şekilde bu matbaanın müdürü olmuştur. Ancak bunun tam olarak ne zaman ve hangi şartlar altında gerçekleştiği bilinmemektedir. Filiz Dı̆̆ıroğlu, Hacı Hüseyin’le ilgili çalışmasında, torununun ifadelerine dayanarak Şirket-i Sahafiye-i İraniye'yi kuranın Hüseyin Efendi olduğunu belirtmiş olsa da görüldüğü üzere bu mümkün değildir. Şirket-i Sahafiye-i İraniye'nin Hacı Hüseyin'le irtibatı ve burada basılan kitaplarla ilgili bkz. Filiz Dığıroğlu, Dersaadet’te Bir Acem Kitapçı: Kitap-Füruş Hacı Hüseyin Ağa İstanbul 2014, s. 19-21. Muinülmülk'ün 1877 'de yazdığı Abter gazetesiyle ilgili bir raporda "gazete bu sefer bir şirket tarafindan çıkarılıyor ve Osmanlılar da gazeteye ortaklar (...) Osmanlı vatandaşları gazeteye ortak olduklarından ve gazetenin üzerinde hükümetin genel nezareti bulunduğundan dolayı gazetenin kapatılması söz konusu olmayacak sanırım” şeklinde bilgi vermesi, bahsedilen şirketin ismi ve mahiyetiyle ilgili soruları cevapsız bıraktığı gibi Ahter’in Şirket-i Sahafiye-i İraniye ile bir irtibatı olması ihtimalini akla getirmektedir. Ancak bu konuda şimdilik başka herhangi bir bilgiye rastlanamamıştır. Rapor için bkz. Sasani, Payitahtın Son Yıllarında, s. 156.

64 Ahter Matbaasının Validehan'da 93 numarada olduğunu gösteren bir kitap kapağı kesiti vardır. Ancak bu kesit sadece matbaanın amblemini göstermektedir ve hangi kitaba ya da seneye ait olduğu belli değildir. Nigar bint Osman tarafından kaleme alınan Efsûs'un 1309 yılında basılan nüshasında "Bâbıâlî karşısında 7 numaralı Ahter Matbaası'nda tab“ olunmuştur" ibaresi yer almaktadır. Ancak bu ibarenin matbaanın değil de kitapçı dükkânının yerini ifade ettiği bir diğer kitap kapağından anlaşılmaktadır. 1308 yılında basılan Macera-yı Aşk için "sahib ve naşiri; Bâbıâlî caddesinde 13 numaralı Ahter Kitabhanesi" ve "Ahter Matbaası'nda tab' olunmuştur" şeklinde bu defa iki ayrı açıklama verilmiştir. Dolayısıyla matbaanın fiili olarak Validehan'da bulunduğu, kitapçının farklı tarihlerde Bâbıâlı̂ caddesi üzerinde zikredilen numaralı dükkânlarda faaliyet gösterdiği düşünülebilir. 
almak üzere verdiği istidadan anlaşıldığı kadarıyla, Hocapaşa civarında Ebussuud Caddesi'nde Alem Matbaası'nın çıktığı mahalle nakletmiştir. İstida neticesi Zaptiye Nezareti tarafından yapılan tetkikte mezkûr yerin matbaa açılması için uygun olduğuna karar verilerek ruhsat düzenlenmiş ve karşıllı̆ında 3 lira tahsil edilmiştir. ${ }^{65}$ Kararın tarihi 2 Cemaziyelevvel 1315/29 Eylül 1897 olduğuna göre taşınma işi bu tarihten sonra gerçekleşmiş olmalıdır. ${ }^{66}$ Yine belgelerden anlaşıldığına göre bu taşınma kararının arkasında Validehan'daki dükkânın matbaa için uygun olmadığına dair Zaptiye Nezareti'nin bir rapor düzenlenmesi ve bu yüzden gazetenin neşrinin durdurulması yer almaktadır. ${ }^{67}$ Ancak Tahir'in yeni bir dükkân bulması üç aydan uzun sürdüğü ve bu esnada nizamname gereği gazete neşri imtiyazı feshedildiği için yeni dükkâna taşınırken gazete neşri imtiyazını da yenilemek durumunda kalmıştır. ${ }^{68}$

1316/1899 tarihli Maarif Nezareti Salnâmesì nin verdiği bilgilere göre ilgili tarihte Bâbıâlî civarında, Ebussuud caddesinde hurufatla Türkçe, Rumca, Ermenice, Fransızca baskı yapan Ahter Matbaası, 1292/1875-76 yılında açılmışır ve sahibi Tahir Efendi'dir. ${ }^{69}$ Matbaanın açılış tarihinden anlaşılıyor ki Tahir, Ahter Matbaası'nı Ahter gazetesini neşretmek üzere kurmuştur. Ancak daha sonraki bir tarihte salnâmede tasrih edildiği üzere çeşitli dillerde kitapların basımına imkân verecek şekilde matbaa için ruhsat almış olmalıdır. Zira matbuat nizamnamesinin altıncı maddesine göre gazete neşri için ruhsat alan kişiler sadece gazetenin basımına hasretmek şartıyla başka bir ruhsat almadan matbaa kurabilirler. Ancak

Şark Ticaret Yillıklari'ndaki verilere dayanılarak hazırlanan Validehan'daki İranlıların dükkânlarına dair listede, Ahter'in müdürü Tahir Efendi'nin 1885-1898 yıllarında handa faaliyet gösterdiği belirtilmiştir. Ancak bu liste oluşturulurken yıllıkların sistemli ve düzenli tutulduğu $1885^{\prime}$ ten itibaren incelendiği göz önünde bulundurulmalıdır. 1898 tarihi, matbaanın buradan taşınmasına dair belgelerle muvafıktır. Bkz. Filiz Dığıroğlu, "İstanbul-Tebriz Ticaret Hattında Validehan (XIX-XX. Yüzyıl)”, Türk Kültürü İncelemeleri Dergisi, sayı 31, güz 2014, s. 69-112 içinde s. 111.

65 BOA, DH.MDK 230/86 (2 Ca 1315/ 29 Eylül 1897).

6613 Mart 1898 tarihinde düzenlenen bir belgeye göre Ahter Matbaası'nın Hocapaşa civarında Ebussuud caddesindeki bu dükkânda bulunduğu görülmektedir. Bkz. BOA, MF.TTD 45/126 (24 L 1315/18 Mart 1898). 1315 yılında Ahter Matbaası'nda basılan Ahmed Hilmi'ye ait Gülzâr-ı Tabiat isimli kitabın kapağında "Ahter Matbaası, Ebussuud Caddesinde, numara 54" ibaresi yer almaktadır. Ayrıca bkz. Halil Rüşdü, Tetebbuât ve Müstahzarâtım, İstanbul 1315, Ahter Matbaası.

67 BOA, DH.MDK 230/87 (3 Ca 1315/30 Eylül 1897).

68 BOA, DH.MDK 230/87 (3 Ca 1315/30 Eylül 1897).

69 Salnâme-i Nezaret-i Maarif-i Umumiyye, 1316, s. 762-763. 
gazete dışında bir şey basmak istediklerinde yeni bir ruhsat almaları gerekmektedir. $^{70}$

Ahter Matbaası'nda basılmış kitaplardan en erken tarihlilerin 1293/1877 yılında basılan Emsile ve Dîvançe-i Hanyevî Şefik Efendi (Hanyalı Şefik Efendi, İstanbul 1293/1877) olduğu görülmektedir. Takip eden iki yılda da Kavâid-i Farisiyye-Kavâid-i Emsile-i Farisiyye-el-Emsileüll-Muhtelife bi-Lisan-ı Farisi (Şeyh Hafız Mehmed Murad Nakşibendî, Ahter Gazetesi Matbaası 1294/1877); Mustafa Hilmi Paşa'nın Vezâif-i Etfâli (1294/1877), Tuhfe-i Sabri an Lisânı Bulgarî (Mustafa Sabri, 1296/1879); Riyâz-ı Asfiyâa (Kâzım Paşa, 1296/1878); Külliyât-ı Dîvân-ı Fuzûlî (1296/1879) ve Sergüzeşt-i Mari Kraliçe ve Kızları (çev. Esad, 1296/1879) kitapları basılmışıtır. Dolayısıyla aslında sadece gazete çıkarmak üzere matbaayı kursa da kısa sürede kitap basımına da geçtiği görülmektedir. Ancak bunun için gerekli ruhsatları almadığı, ruhsatsız kitap bastığı için yapılan baskınlar ve kovuşturmalardan anlaşılmaktadır. Yapılan bir teftişte tutulan kayıttaki "Tahir Efendi'nin Validehan'da bulunan diğer matbaasında (Şirket-i Sahafiye-i İraniye kastediliyor olmalı) olduğu gibi burada dahi ruhsatsız ve tab'ı memnu bir takım kütüb ve evrak tab eylemekde olduğu idare-i acizîce dahi malum ve müsbet ve halbuki Ahter gazetesi matbaasının gazeteden başka bir şey basması matbaalar nizamnamesinin 7. maddesi hükmünce gayr-1 caiz bulunduğundan" ifadeleri bunu açıkça ortaya koymaktadır. ${ }^{71}$

Matbaasında ruhsatsız kitap bastığı için sık sık resmi makamlarla sorunlar yaşayan Tahir'in bazen araya sefareti koymak suretiyle cezalardan ya da kitap

7021 Cemaziyelahir 1312/20 Aralık 1894 tarihli nizamnamenin ilgili maddesi için bkz. Salnâme-i Nezaret-i Maarif-i Umumiyye, 1316, s. 171-172. 17 Safer 1292 tarihli bir belgede ise Tahir'in ruhsatsız matbaa açıp faaliyette bulunduğu gerekçesiyle matbaa taşları ve cüzlerine el konulduğu belirtmektedir. Bkz. BOA, MF.MKT 26/123 (17 S 1292/25 Mart 1875).

71 BOA, DH.MDK 220/114 (8 M 1310/2 Ağustos 1892). Aynı teftişe dair düzenlenen başka bir belgedeki "gazetesi namına bila-ruhsat küşad ettiği mezkûr matbaada mugayir-i nizam kütüb ve resâil ve evrâk-1 saire tab` eylemekte olduğundan ve bu muamele matbaalarda câri olmak sair gazetelere münhasır ve mahsus muhtemel bulunduğundan mevcut gazete matbaalarından hangileri gazetelere münhasır ve hangileri de kütüb ve resâil ve evrâk-1 sâire tab' 1 caiz olduğunu mübeyyin bir defterin tanzim ve isrası hakkında vaki olan işâr-1 âlîleri üzerine ol babda matbuat idaresince tanzim olan defteri leffen irsal kılınmış olmakla" ifadeleri ise gazete için açılan matbaada ruhsatsız kitap basımının Tahir dışındaki pek çok kişi tarafından da yapılan bir usulsüzlük olduğu ve teftişler esnasında matbaaların ayırt edilebilmesi için bir defter düzenlendiğini anlatmaktadır. Bkz. BOA, DH.MKT 1985/65 (16 M 1310/10 Ağustos 1892). 
müsaderelerinden kurtulmaya çalıştığı görülmektedir. ${ }^{72}$ Sadece Tahir Efendi'nin değil diğer İranlı kitapçıların da bu yönteme başvurduğu; İran tebasından olmakla böyle bir hakka sahip olduklarını düşündükleri ancak bu talebin nizamnameye aykırı olduğu gibi "sefaretten memur vüruduna intizar edildiği halde müsaderesi lazım gelen kütüb ve resâilin gizlenmesi veya bir tarafa kaldırılması muhtemel olabileceği” gerekçesiyle reddedildiği görülmektedir. ${ }^{73}$ Yine de İran sefaretinden tercüman Cevad Bey'in zabıtanın İranlı kitapçılara yaptığı teftiş ve baskınlarda hazır bulunduğu ve müdahil olduğu çeşitli vakalar zaptiye kayıtlarinda mevcuttur. ${ }^{74}$

Matbaanın serencamı, 1319/1902 yılında basılan kitaplarla son bulmaktadır. Çiçek Yahud Kendi Kendine Çiçekçilik (çev. Çerkeşşeyhîzâde Tevfik, 1319/1902); Bahar Ĕ̆lenceleri, Seviyor Muyum Seviyor Mu? (Mehmed Celal, 1319/1902); İki Kız (Mehmed Celal, 1319/1902); Gülünçlü Efsaneler: Ez Müntehabât-ı Mehmed Hilmi (Mehmed Hilmi, 1319/1902) bu yılda basılan kitaplardır. ${ }^{75}$

Matbaanın kapanma nedeni Tahir' in Maarif Nezareti Encümen-i Teftiş ve Muayene Heyeti azalığıdır. "Ebussud caddesinde vaki Ahter Matbaası sahibi Tahir Efendi'nin nezaret-i âcizî Teftiş ve Muayene Heyeti azasından olmasından ve memuriyet-i resmiyyeyi haiz bulunmasından dolayı matbaacılık mesleğinde devamı muvafik-1 usul ve nizam olamayacağına binaen" kapatılan matbaasının alet edevatının nezaret tarafından satın alınmasına karar verilmiş; kurulan bir heyet marifetiyle bunların satış bedeli "mecmu esmanı sim mecidi 20 kuruş hesabıyla

72 "Ahter Matbaası’nda ekseriyetle bila-ruhsat kütüb ve resâil ve evrâk-1 muzırra tab ve neşr olunmakta olduğu icra kılınan tahkikattan anlaşılmasına binaen ale'l-usul matbaanın teftişi lazım gelerek müracaat olundukta sahib-i imtiyazı teb`a-i İraniye’den Tahir Efendi sefarethaneden memur hazır bulunmadıkça gerek müfettiş ve gerek memur sıfatıyla hiçbir kimseyi kabul etmeyip şayet kuvve-i cebriye istimale kalkışılacak olursa mukabelede bulunacağını ifade eyledikten”. Bkz. BOA, MF.MKT 145/10 (17 Z 1309/13 Temmuz 1892). Benzer bir olay için bkz. BOA, DH.MDK 220/114 (8 M 1310/2 Ağustos 1892).

73 BOA, MF.MKT 145/10 (17 Z 1309/13 Temmuz 1892). 1894 tarihli Matbuat nizamnamesindeki ilgili on altıncı madde için bkz. Salnâme-i Nezaret-i Maarif-i Umumiyye, 1316, s. 175-176.

74 BOA, MF.TTD 35/35 (12 Ş 1314/16 Ocak 1897); BOA, MF.TTD 37/127 (19 Ra 1315/18 Ağustos 1897).

75 Hakkı Tarık Us Kütüphanesi 18830 demirbaş numaralı "Şafak Kütüphanesi Esami-i Kütübü”nün, 1328 yılında Ahter Matbaasında basıldığı kaydedilmiştir. Ancak bu matbaanın kapanmasından çok sonraki bir zamana işaret ettiğinden 1318 yerine 1328 yazılmak şeklinde bir hata söz konusu olmalıdır. Nitekim 18838 demirbaş numaralı Kütübhane-i Cihan Esâmi-i Kütübü, 1318/1901 yilında basılmışır. 
34.000 kuruş" olarak belirlenmiş ve nezaret adına satın alınması 3 Cemaziyelahir 321/27 Ağustos 1903 tarihinde onaylanmıştır. ${ }^{76}$

\section{Ahter Gazetesi}

İran dişında Farsça neşredilen ilk ve en önemli gazete olarak İran ve Osmanlı matbuat tarihi için önemli bir basamak addedilen Ahter, ${ }^{77}$ Muhammed Tahir Tebrizînin şahsi gayretlerinin ve İstanbul'da mukim İranlı entelektüellerin fikri katkılarının yanı sıra iki devletin farklı dönemlerdeki finansal desteklerinin bir araya gelmesiyle kesintilerle de olsa yirmi yıllık bir neşir hayatı (1876-1896) yaşamıştır. $^{78}$

Dönemin İstanbul'daki İran sefiri Mirza Muhsin Han Muinülmülk'ün (1820-1899) teşviği ve İran devletinden sağladığı maddi desteği ile gazetenin sahibi ve müdürü olarak Muhammed Tahir, gazeteyi neşretmeye başlamıştır. Sefaret çalışanlarından naib-i evvel ve tercüman Mirza Necef Ali Han da Tahir'e bu işte yardımcı olmak üzere görevlendirilmiştir. Dolayısıyla Muhammed Tahir gazetenin hem kurucusu ve hem de mali ve idari açıdan mesul müdürüdür. ${ }^{79}$

"Çeşitli günlük haberler, siyaset, politika, ticaret, ilim, edebiyat ve umumun faydasına olan diğer hususlarda söz söylemek" ${ }^{80}$ üzere ilk sayısı 16 Zilhicce 1292/13 Ocak 1876'da yayınlanan Ahter, İran ve Osmanlı hükümetleri tarafından finanse edilmiştir. Şah, İstanbul'da Farsça bir gazete yayınlanmasının,

76 BOA, ŞD 218/60 (15 Ş 1321/6 Kasım 1903). Ayrıca bkz. BOA, Y.MTV 254/41 (8 L 1321/29 Aralık 1903); BOA, DH.MDK 257/48 (9 Mart 1320/22 Mart 1904).

77 Abter gazetesiyle ilgili çeşitli çalışmalar yapılmıştır. Son dönemde yüksek lisans ve doktora düzeyinde özellikle İranlı ögrencilere yaptırılan bazı vasıfsız tezleri bir kenara koyarsak bu konudaki ilk çalışmalardan Les Iraniens d'Istanbul kitabında yer alan Orhan Koloğlu ve Anja PistorHatam'ın makaleleri ile yeni çalışmalardan Tanya Lawrence'ın yayınlanan tezi zikredilebilir. Bkz. Orhan Koloğlu, "Un Journal Persan d'Istanbul: Akhtar", Les Iraniens d'Istanbul, ed. Thierry Zarcone-F. Zarinebaf-Shahr, Istanbul-Teheran, 1993, s. 133-140; Anja Pistor-Hatam, "The Persian Newspaper Akhtar as a Transmitter of Ottoman Political Ideas", Les Iraniens d'Istanbul, ed. Thierry Zarcone-F. Zarinebaf-Shahr, Istanbul-Teheran, 1993, s. 141-147; Tanya E. Lawrence, Akhtar: A Persian Language Newspaper Published in Istanbul and The Iranian Community of The Ottoman Empire in The Late Nineteenth Century, İstanbul 2015. Ayrica bkz. Pervin, Tarih-i Ruznâme, I, 246-265.

78 Pervin, Tarih-i Ruznâme, I, 249-253.

79 Sasani, Payitahtın Son Yullarında, s. 155; Pervin, Tarih-i Ruznâme, I, 251.

80 Abter, I/1, 16 Zilhicce 1292/13 Ocak 1876, künye altı yazısı, s. 1. 
Osmanlı topraklarında yaşayan İranlıları ve Farsça bilen Osmanlıları etkileme aracı olarak iş görebileceği düşüncesiyle böyle bir gazetenin neşrini desteklemiş ve Osmanlı gazetelerinin "asılsız iddiları"na karşı bir silah olarak Abter 'i kullanmak istemiştir. $^{81}$

Yayınlanması için gerekli maddi desteğin bir kısmını da İstanbul'da yaşayan İranlı tüccarların sağladığı gazetenin, asıl amacı İstanbul'da yaşayan İranlılar'ı imparatorluk ve Avrupa'da yaşanan gelişmeler ile ilgili olarak bilgilendirmek ve eğitmektir. Nâsırüddin Şah’ın (1848-96) da bizzat abone olduğu ve yazılarını büyük bir ilgi ile takip ettiği Ahter, Tebriz, Tahran, İsfahan ve Bakü'de, Hindistan'da ise Haydarabad ve Lahore gibi şehirlerde dağıtılmıştır. ${ }^{82}$

İlk altmış sayının ardından maddi sıkıntılar yaşayan gazete, daha sonra başka sebeplerle tekraren yaşanacak ilk fasılasını vermiştir. Muinülmülk'ün İran Hariciye Vezareti'ne yazdığı mektuplardan birinde dile getirdiği "Ahter gazetesi altmış sayı çıktı ve kapandı. 100 lira buyurduğunuzda yeniden çıkacaktır" ${ }^{83}$ talebi karşılanmamış olsa gerek ki 25 Zilhicce 1293/11 Ocak 1877'de yeniden neşre başlaması, II. Abdülhamid'in mali desteği ile mümkün olmuştur. Bunda Sefir Muinülmülk'ün padişahla dostluğu ve yakın münasebetinin etkisi çok büyüktür. ${ }^{84}$

81 Pistor-Hatam, “The Persian Newspaper Akhtar”, Les Iraniens, s. 141-142.

82 Fariba Zarinebaf, "Alternatif Moderniteler: Osmanlı İmparatorluğu ve İran'da Meşrutiyetçilik", Dîvân, 2008/1, s. 64-65.

83 Sasani, Payitabtin Son Yillarinda, s. 155.

84 1873-1891 yılları arasında İran'ın İstanbul sefirliği görevini ifa eden Mirza Muhsin Han Muinülmülk'ün sefareti ve sultana yakınlı̆̆ıla ilgili bkz. Johann Strauss, "La Presence Diplomatique Iranienne”, Les Iraniens, s. 11-32 içinde s. 19-20. 1293 yılının Zilhicce ayında (Ocak 1877) Muinülmülk Hariciye Vezaretine şöyle yazmıştır: "Kurban bayramında Padişahın huzuruna çıktım. Ahter gazetesinin kapanmasından dolayı duyduğu üzüntüyü belirttiler ve "İstanbul'da Türkçenin temeli ve dillerin süsü olan Farsça dilinde bir gazetenin bulunmaması üzüntü verici” diyerek Farsça bir gazetenin yayınlanması için ısrarcı oldular. 28 Muharrem 1294 'te (12 Şubat 1877) Padişahın teşvikleri sonucunda Abter gazetesi yeniden yayın hayatına başladı. İlk nüshayı huzura gönderdim ve 55 kişi abone olup parasını gönderdi. Yirmi nüsha Hariciye Vezaretine gönderildi. On nüshası Maarife, on nüshası saraya ve beş nüshası şehzadelere dağıtıldı. Bir nüsha da ekselansları bizzat istediler. Sanırım Ağa Muhammed Tahir için sürekli bir bağışta bulunacaklar. Mümkün olan her vesile ile İran haberlerini gönderin. Gazete bu sefer bir şirket tarafından çıkarılıyor ve Osmanlılar da gazeteye ortaklar. Hacı Mirza Necef Ali Han sefaretten ayrılarak gazetenin bürosuna yerleşti. Bu hafta kendi anlayışına göre devlet-i aliyye ile rusya arasındaki ilişkiler ile ilgili bir yazı yazmış. Ortalığı öylesine birbirine karıştırdı ki düzeltmek oldukça zor. En azından bazı nüshaları geri topladım. İdarenin müdürü Hacı Rızakuli'ye ve imtiyaz sahibi Ağa Muhammed Tahir'e fırça attım. Osmanlı vatandaşları 
Ahter'i dönemin Osmanlı basınının genel özelliklerini haiz bir yayın ${ }^{85}$ olarak değerlendiren Koloğlu, Abdülhamit tarafından verilen desteğin de basının gelişmesini desteklemek maksadına matuf olduğunu ileri sürmüştür. ${ }^{86}$ Ancak bu desteği, İran'la ilişkileri kontrol altında tutma ve İslam birliği siyasetinin mütemmim bir cüzü olarak değerlendirmek daha uygun görünmektedir. ${ }^{87}$

Böylece gazete yayına başladıktan sonra İran hükümetinin kontrolünden çıkmıştır. İlk sayıdan itibaren Osmanlı meşrutiyetinin ilanını sağlayan olaylar üzerine yazılar yayınlamak suretiyle anayasa ve meşrutiyet fikirlerini savunmuştur. Giderek artan bir şekilde İstanbul'daki İranlı siyasi sürgünlerin etkisi altına girmiş ve 1892'de İran Tütün Rejisi'yle ilgili olaylarda takındığı tavır nedeniyle İran'da yasaklanmıştır. ${ }^{88}$

gazeteye ortak olduklarından ve gazetenin üzerinde hükümetin genel nezareti bulunduğundan dolayı gazetenin kapatılması söz konusu olmayacak sanırım. Dağıtımını engelleyemediğimiz nüshalardan diğer gazetelerin alıntı yapması da oldukça muhtemeldir. Ruslar'ın da bize başvurması ve konuyla ilgili görüşlerimizi istemesi beklenmektedir. Kendisinin sefaretten ayrıldığını ve resmi bir görevi bulunmadığını söyleyeceğim sanırım. Ruslar'ın isteği karşısında tanınmamış bir İranlı’nın adına duyuruda bulunacağım. Gazetenin yirmi nüshasını katırlarla gönderdim. Hediye olarak dağıtılmak üzere Abter yönetimine 300 tümen gönderiniz. Türkçe gazetelerin saldırılarını engelleyebilmek için bundan daha güçlü bir silahımız yok.” Bkz. Sasani, Payitahtın Son Yillarında, s. 155-156. Niya, Abter'in ikinci kez neşriyle ilgili Han Melik Sasani'nin verdiği tarihin hatalı olduğunu ve gazetenin sefirin Sultan'la bayramlaşmasından on beş gün sonra 25 Zilhicce 1293'te yayınlandığını belirtmiştir. Han Melik Sasani’nin verdiği 28 Muharrem 1294 tarihinin de sefir tarafından Hariciye’ye gönderilen mektubun tarihi olabileceğini iddia etmiştir. Bkz. Niya, İran ve Osmanî, I, 283.

85 Koloğlu, "Un Journal Persan d'Istanbul: Akhtar", Les Iraniens, s. 133.

86 Koloğlu, "Un Journal Persan d'Istanbul: Akhtar", Les Iraniens, s. 135.

87 Zarinebaf, "Alternatif Moderniteler”, s. 48-49, 69. Çalışmasının bir bölümünü bu konuya hasreden Tanya Lawrence, 1881-1882 Mısır krizi sürecinde gazetenin İslam birliği siyasetini destekleyen yazıları üzerinden geniş bir değerlendirme yapmıştır. Bkz. Lawrence, Akhtar: A Persian Language Newspaper, s. 67-96. Bu minvalde gazetede yayınlanan "İttihad-1 İslam" başlıklı yazı çarpıcı bir örnektir. Bkz. Ahter, VIII/39, 20 Şevval 1298/14 Eylül 1881, s. 310-311.

88 Pistor-Hatam, “The Persian Newspaper Akhtar”, Les Iraniens, s. 141-142. Abter, Kanun'un yayınlanmasından tam on beş sene önce kanun fikrinden bahsetmesiyle, Kanun'un babası olarak nitelendirilmiştir. Kanun da Ahter' in bu anlamdaki hizmetlerini "Ahter gazetesi, İran devletine ve milletine yetmiş vezir-i azamın yaptığı hizmetten daha fazla hizmet ediyor" şeklinde dile getirmiştir. Bkz. Niya, İran ve Osman̂̂, I, 277-278. İran matbuat tarihinin en önemli gazetelerinden 1890 yllında Londra’da Malkum tarafindan yayınlanan Kanun hakkında bkz. Pervin, Tarih-i Ruznâme, I, 268-287. 
Gazetenin yayın politikasındaki değişikliklere paralel olarak İran’a girişi yasaklandığı gibi dönem dönem de Osmanlı matbuat idaresi tarafından yayını durdurulmuştur. ${ }^{89} \mathrm{Bu}$ yayını durdurma kararlarında bazen İran'ın baskısı etkili olmuştur. Örneğin 1308 yılındaki yedi ay süren bir yasakta, Ahter'i destekleyen Muinülmülk'ün İstanbul sefirliği görevinden alınmasının doğrudan bir ilişkisi vardır. Ahter'de Şah aleyhinde yazı yayınlanmasına müsaade ettiği için görevden alınan Muinülmülk, Tahran'dan gelen baskılara rağmen Ahter'i himaye etmeye devam etmiş, görevden alınması da Ahter için sonun başlangıcı olmuştur. ${ }^{90}$ İran' ın Muinülmülk'ten sonraki İstanbul sefiri Nâzımüddevle Dîbâ, Abter'in yeniden yayınlanması için gerekli girişimlerde bulunan ve İran devletinin mali desteğini sağlayanlardan biridir. Tahir'i İran devleti saflarına çekme ve Ahter'i İran rejim muhalifi olmaktan çıkarma hususunda büyük bir paya sahiptir. Ahter' in, 1309 Safer'inde (Eylül 1891) başlayan bu yeni döneminde rejim yanlısı bir tutum içine girdiği görülmektedir. ${ }^{91}$ Bir süre sonra yine yayınları İran’’ rahatsız etmeye baş-

89 Niya, İran ve Osmanî, I, 349-351. Yayının durdurulması ve yeniden neşir talepleriyle ilgili bazı belgeler için bkz. BOA, DH.MDK 221/43 (23 C 1310/12 Ocak 1893); BOA, DH.MDK 228/120 (14 Ş 1314/18 Ocak 1897); BOA, DH.MDK 231/160 (24 Za 1315/16 Nisan 1898).

90 Niya, İran ve Osman̂̂, I, 351. “Görüldüğü gibi Kalküta'da basılan Hablu'l-Metin gazetesinin Hindistan veliahdından ilham aldığı gibi İstanbul'daki Ahter gazetesi de Osmanlı sultanından ilham alıyordu. İran-Rus müzakereleri kesildikten sonra da İttihad-1 İslam için kalem oynatmaya başlamıştı. Samerra’daki Şiiler’in katledilmesini, Kerbela-yı Mualla’nın sultanın emriyle yağmalanmasını ise duymazlıktan geliyordu. Muinülmülk’ün sefaret süresinin sona ermesinin ardından Ahter gazetesi de yayınına son verdi. Gazete yayımına 1310 (1892) yılına kadar devam etti. Bu tarihte Tahran vezaret-i hariciyesinden İstanbul Sefareti'ne Ahter gazetesinin sultanın bankası hakkında olumsuz haberler yazdığı ve bunun engellenmesi gerektiğine dair bir yazı gelince Muinülmülk "bankaların şikâyeti varsa bunu Osmanlı matbuat dairesine yapsın" cevabını vermiştir.” Bkz. Sasani, Payitahtın Son Yıllarında, s. 157.

91 Niya, Iran ve Osmanî, I, 354-355. Bu dönemde İran'ın Ahter'i kendi safına çekme ihtiyacı, yeni sefir Esedullah Nâzımuddevle’nin İstanbul'dan veziriazam Eminüssultan'a yazdığı 14 Cemaziyelevvel 1309/16 Aralık 1891 tarihli mektubundaki şu ifadelerinden açıkça anlaşılmaktadır: "Daha önce de arz ettiğim gibi Ahter' in yayınlanması için izin alındığı zaman Ağa Muhammed Tahir çok perişan bir durumdaydıv ve onun neşrine gücü yetmiyordu. Şah'ın teveccühünden emin olduktan sonra borç harç bu iki üç ay içerisinde gazete neşrini hale yola koydu. Dün mahza Şah'a teşekkür için sefarete geldi ve gazeteyi neşre gücünün yetmediğini de zımnen bildirdi ve perişanlığını ızhar etti... Abter, Osmanlı gazeteleri karşısında harb aleti ve silahtır. Şah tarafından istimdat buyrulsun da Ahter vaad edildiği gibi çıkmaya devam etsin." Eminüssultan bu mektubu Şah’a arz etmiş ve "elbette bu gazeteye her türlü yardımda bulunun. Özellikle Şeyh Cemaleddin ve onun Arapça kitaplarına karşı reddiyeler yazılsın ve neşredilsin, bu çok gerekli” cevabını almıştır. Eminüssultan, İstanbul'a Nâzımuddevle’ye cevaben şöyle yazmıştır: “Malkum'dan ve Kanun'undan haberdarsınız. Şimdi de Şeyh Cemaleddin Londra’ya gitti ve ona 
layan gazetenin ülkeye girişi yeniden yasaklanmıştır. Nâsıruddin Şah'ın 1313'te suikasta kurban gitmesi ve Seyyid Cemaleddin Afganî ve gazetenin yazarlarından olan İttihad-ı İslam taraftarı bazı isimlerin itham edilmesi neticesinde gazetenin yayını durmuş ve bir daha yayınlanmamıştır. ${ }^{92}$ Gazetenin yayınlanan son sayısı 24 Safer 1314/4 Ağustos 1896 tarihini taşımaktadır.

Ahter, İstanbul'daki İranlı yazar ve entelektüellerin çoğunlukla imzasız bazen de müstear isimle, nadiren kendi isimleriyle yazılar yayınladıkları bir gazetedir. Çoğunlukla liberal, meşrutiyet yanlısı olup İran'dan kaçan ya da sürgün edilen kişilerden müteşekkil bu yazar kadrosu, yazılarında Nâsıruddin Şah’ın istibdadını eleştirmek ve halkı aydınlatmak amacını taşımışlardır. ${ }^{93}$ Ahter'de imzası bulunan kişiler ise her sayının sonunda adı olan Muhammed Tahir'in dışında İran sefaret mütercimi Mirza Necef Ali Han, daha sonra Hurşid gazetesini neşredecek olan Mirza Mehdi Han Tebrizî, Mirza Ağa Han Kirmânî ve Şeyh Ahmed Ruhi Kirmânîdir. ${ }^{94}$ Muhammed Tahir, Ahter' in sahibi ve müdürü olarak ve Mirza Mehdi de redaktörü olarak İran hükümeti tarafından üçüncü dereceden Şîr-i Hurşid nişanına layık görülmüşlerdir. ${ }^{95}$

Ahter'in, dönem dönem İran'a temayül göstermesi, dönem dönem de Sultan Abdülhamid yanlısı bir tutum takınması, gazetenin sahibi ve müdürü olarak pragmatist bir tutum geliştiren Muhammed Tahir ile yazarlar arasında ihtilaf ve görüş ayrılıklarına yol açmıştır. ${ }^{96}$ Bu görüş ayrılıkları maddi anlaşmazlıklarla da birleşince gazetenin yazarlarından üç önemli ismin birden ayrılmasıyla sonuçlanacak bir tartışmaya dönüşmüştür. Yıllarca kendine ait sütunda yazılar yazan Mirza

katıldı. Şah aleyhinde kitaplar ve gazeteler yayınladılar. Ahter' in ilk sayısında onun rezillikleri, küfrü ve habisliği hakkında yazı yazılsın ki halk da bilgilensin, o kitapları yazanın müctehid olmadığı gibi bir şeytan ve mahza küfür olduğunu öğrensinler." Bundan sonra da Malkum ve Seyyid Cemaleddin Afganî aleyhinde yazılar, açık ve örtük olarak yayınlanmaya devam etmiştir. Bkz. Niya, Iran ve Osmanî, I, 355-357.

92 Niya, İran ve Osmanî, I, 358-359.

93 Niya, Iran ve Osmanî, I, 277.

94 Pervin, Tarih-i Ruznâme, I, 250-251.

95 Koloğlu, “Un Journal Persan d'Istanbul: Akhtar”, Les Iraniens, s. 138.

96 Niya, İran ve Osmanî, I, 343-344. Mirza Muhammed Hüseyin Ferahanî, Safer 1303/Kasım 1885 tarihinde ziyaret ettiği Ahter bürosunda görüştüğü Ahter 'in müdürü hakkında şunları yazmıştır: "inançlı ve dindar olduğu için İran devleti lehine çalışmayı imanının şartlarından biri olarak kabul ediyor. Bazen gazetesinde İran devleti hakkında bir şeyler yazıyorsa da devletin iyiliğini istemekten başka bir maksadı yok ve bunu inancının ihlası ve vatanseverlik olarak kabul ediyor." Bkz. Caferiyan, Sefernâmehâ, V, 265. 
Ağa Han Kirmânî, 1308 yılında Malkum’a yazdığı bir mektupta, "İstanbul'da matbuatın durumu oldukça zor. Fikir hürriyeti ve kalem özgürlüğü hiç kimse için mümkün değil" şeklinde halinden dert yanarak kendisine iş bulmasını rica etmiştir. ${ }^{97} 1309$ yılında yeniden ve bu defa İran'daki rejim yanlısı yazılarla yayın hayatına dönen Ahter'den ayrılmak durumunda kalmış ve yakın dostları Mirza Habib Isfahanî ve Ahmed Ruhi Kirmani'yi de yanında götürmüştür. Ayrılırken Tahir' in rejim yanlısı ve reji karşıtları aleyhinde yayın yapmak için rüşvet aldığı iddiasında bulunmuştur. ${ }^{98}$ Mirza Ağa Han Kirmânî, Habib Isfahanî ve Şeyh Ahmed Rûhî ile birlikte 1892 'de Ahter'le ilişiklerini tamamen koparmışlardır. İpleri koparan sebep ise Tahir'in damadı Mirza Hüseyin Şerif'le yaşadıkları tartışmadır. Mirza Hüseyin Şerif, İngiliz bir tanıdığına vermek üzere Mirza Ağa Han Kirmânîden Bâbilik üzerine yazdığı kitabının bir kopyasını istemiş ve telif hakkını vaad etmiş ancak bu şekilde kitabın bir nüshasını ele geçiren Hüseyin Şerif, kitabı bir grup İranlının huzurunda sesli bir şekilde okuyarak Kirmânî yi sapkınlık ve dinsizlikle itham etmiştir. Yaşanan bu olay mezkûr üç yazarın bir daha Ahter'de yazı yayınlamamasıyla neticelenmiştir. ${ }^{99}$

Browne, ilk defa 1877-8'de Kirman'da iken fark ettiği ve İngiltere'ye döner dönmez posta yoluyla aboneliğini başlattığı Abter' in "İran'da okunmaya değer tek Farsça gazete” olduğunu dile getirmiş̧ir. ${ }^{100}$ Gazete İran'da o kadar önemli hale gelmiştir ki Abter ismi, gazete satıcılarına verilir olmuştur. Sohbetlerde ve toplantılarda güncel olaylar tartışılırken Abter'de yazılanların otoritesi açıkça hissedilir hale gelmiştir. Gazete zamanla Kafkasya, İran, Türkistan, Hindistan, Irak ve benzeri yerlerde o kadar meşhur olmuştur ki Kafkasya'nın bazı bölgelerinde gazete okumayı uygunsuz ve sakıncalı bulan kişiler, gazete okuma alışkanlığı olanları

97 Niya, Iran ve Osmanî, I, 344.

98 Bu söylentiler ve Ahter'de verilen cevap ve değerlendirmeler için bkz. Niya, İran ve Osmanî, I, 422-423.

99 Lawrence, Akbtar: A Persian Language Newspaper, s. 39-40. Ahter'de yayınlanan Bahâ̂lerle ilgili yazılar, İran dışında pek çok yere dağılan Bahâî cemaatinde oldukça büyük bir rahatsızlık yaratmış olmalı ki ilgili yazılara cevap vermek üzere Aşkabat'taki Bahâî topluluk, bir gazete yayınlanması ve matbaa kurulması yönünde girişimlerde bulunmuştur. Ancak bunun gerçekleşmesi yıllar sonra mümkün olmuştur. Bkz. Farzin Vejdani, “Transnational Baha’i Print Culture: Community Formation and Religious Authority, 1890-1920”, Journal of Religious History, Vol. 36, No. 4, December 2012, s. 510.

100 "Even when I was in Persia in 1887-8 the only Persian newspaper worth reading was the Akh$\operatorname{tar}$ ("Star"), published weekly at Constantinople." Edward Browne, A Literary History of Persia, Cambridge 1930, IV, 468. 
"Ahterî-mezheb/Ahter mezhepli” olarak isimlendirmişlerdir. ${ }^{101}$ Yine Browne’ın tabiriyle, "medeniyetin ışı̆̆ının, sayfaları arasından doğup insanların kalplerine yansıdığı” Ahter, gazete okuma zevkini aşılamış ve etrafında kültürlü, yetkin ve entelektüel insanların toplandı $\breve{g}_{1}$ bir merkez haline gelmiştir. ${ }^{102}$

İran ve Osmanlı dışında, özellikle Kafkasya ve Hindistan'da çok sayıda okuyucuya ulaşan, Tebriz, Tahran, Reşt, Tiflis, Bakü, Bombay, Midras, Haydarabad, Leknev, Lahor, Karaçi, Kerbela, Musul, Beyrut gibi şehirlerde temsilcilikleri olan ${ }^{103}$ Ahter' in etkisi, İngiliz raporlarına da yansımış, 1894 yılında Hindistan'dan yazılan bir raporda “Bu gazete, haftalık olarak İstanbul'da neşrediliyor ve İran ve Orta Asya'da geniş bir şekilde dağıtılıyor. Filhakika, bu gazetenin yaygınlığı hepsinden fazla ve Tahran, Isfahan ve de Bombay'da neşredilen bütün diğer Farsça gazetelerden daha makbul. Kendi gözümle gördüm ki Herat'ın yöneticisi onu okuyor ve onun gibi pek çokları da o gazeteyi düzenli bir şekilde alıyorlar ve fikirlerini ona göre şekillendiriyorlar. İran'daki genel hissiyat, Ahter'de yazılan her şeyin hakikat olduğu yönündedir" ifadelerine yer verilmiştir. ${ }^{104}$

\section{Kitapçı Tahir Neler Basardı/Satardı?}

Abter gazetesinin ilk sayısının son sayfasında matbaayla ilgili bir ilan yayınlanmıştır. İlana göre Ahter Matbaası'nda, litografya ve tipografya baskı teknikleriyle, uygun fiyatlara ve en güzel şekilde her türlü kitap, risale ve evrak basılmaktadır. Söz konusu ilanda Farsça, Türkçe, Fransızca kartvizit, ticaret defteri ve her türlü resmi evrak da basıldığı belirtilmektedir. ${ }^{105}$ Dolayısıla Kitapçı Tahir’in gerek basmak gerekse satmak için olsun elinden geçen kitaplar nelerdi diye düşünüldüğ̈̈nde ilk yapılması gereken Ahter Matbaası'nda bastığı kitapların tespitidir.

101 Browne, The Press and Poetry, s. 17-18. Ahter' in İranlıların düşünce dünyasına etkileri için bkz. Niya, Iran ve Osmanî, I, 278-279.

102 Browne, The Press and Poetry, s. 17-18. 1900 yılında Kahire'de yayınlanmaya başlayan Perveriş gazetesinde, Muzafferüddin Şah'ın Muhammed Tahir ve oğullarına iltifatını söz konusu eden bir haberdeki şu ifadeler, Ahter'in muasırları tarafından nasıl takdir edildiğini ve açtığı yolun takip edildiğini göstermesi açısından oldukça mühimdir: "Doğrusu Ağa Muhammed Tahir de bunların hepsine layıktır. Zira gazete yazarlığını ilk başlatan kişidir. 30 yıl önce İstanbul'da Ahter'i neşretti ve insanları gazete okumaya alıştırdı." Bkz. Perveriş, I/22, (26 Receb 1318/22 Kasım 1900), s. 424'den nakleden Niya, Iran ve Osmant̂, I, 929.

103 Niya, İran ve Osmanî, I, ,281.

104 Niya, İran ve Osmanî, I, 280.

105 Ahter, I/1, 16 Zilhicce 1292/13 Ocak 1876, s. 4. 
Taramalar neticesinde şimdilik 117 kitaplık bir liste oluşturulmuştur. ${ }^{106}$ Ahter Matbaası'nda bastığı kitapları öncelikle kendi dükkânında satışa çıkardığı açıtır. Bundan dolayı bastığı kitapların listesi aynı zamanda sattıklarını da göstermektedir. O yıllarda faaliyet gösteren matbaaların bastığı ya da kütüphanelerin sattığı kitaplara dair fihrist eserler yayınlanmışıır ${ }^{107}$ ancak Ahter'le ilgili böyle bir fihrist hazırlandığına dair bir kayıt yoktur.

Kitapçı Tahir'in ne tür kitaplar bastığını ve sattığını arşiv belgelerinden takip ettiğimizde bu belgeler ya bir eser basımı için ruhsat talebi ve buna verilen cevaplar ya da matbaa ve kitapçı dükkânının teftiş raporlarıdır. Dolayısıyla bu raporlarda adı geçenler çoğunlukla ya çeşitli sebeplerle mahzurlu görülen "muzır neşriyat" veya "âsâr-1 memnua" ya da ruhsatsız basılmış kitaplardır.

Mekteb-i Sanayi-i Şahane'den hurufat alımı yapmak için verdiği bir istidadan, Ayıntâbî Mehmed Efendi'nin (1111/1699) Kur'ân-1 Kerîm'in ilk Türkçe matbu tefsiri olan eseri Tibyân ve Vâiz-i Kâşifî, (910/1504-1505) tarafindan yazılan ve İsmail Ferruh Efendi tarafından tercüme edilen Mevâkib tefsirlerini ruhsatlı olarak bastı̆̆ı ve sattığı anlaşılmaktadır. ${ }^{108}$ Aynı şekilde dükkânındaki İbn Ebü'l-Hadid'in (655/1257) yazdığı Şerh-i Nehcüll-Belâ̆ga da satışında mahzur görülmeyen eserlerdendir. ${ }^{109}$

Muzır neşriyata örnek olarak ise dükkânda altı mecidiye satılan "ehl-i sünnet hakkında pek çok ta'n ve teşni i havi” Tefsir-i Sâfí zikredilebilir. Dükkânda ele geçirilen bu kitap Tetkik-i Müellefat heyeti tarafindan incelenip "ekser-i mündericatı rafz ve ilhaddan ibaret olduğundan heman toplattırılarak men-i tedavülü”ne

106 Ahter Matbaası'nda basılmış kitaplardan künye bilgisine erişilenlerin listesi ektedir. Ancak özellikle Farsça kitaplar açısından bu listenin çok eksik olduğunu itiraf etmek gerekir.

107 Ahter Matbaası'nda basılan eserler arasında bu türden fihristler vardır: Kütübhane-i Cihan Esâmi-i Kütübü (İstanbul 1318/1901), Kütübhane-i İrfan Esâmi-i Kütübü (İstanbul 1316/1898), Şafak Kütübhanesi Esâmi-i Kütübü, (İstanbul 1318/1901).

108 BOA, DH.MDK 237/136 (19 M 1318/19 Mayıs 1900). Eski Harfli Türkçe Basma Eserler Bibliyografyası'nda bu tefsirlerle ilgili kayıtlar şöyledir: Tefsir-i Tibyân, çeviren ve tefsir eden: Mehmed Ayıntabî, Ahter-Alem-Ârif Efendi Matbaaları, İstanbul 1317/1900, 1-4 Cilt (kenarında Tefsir-i Mevâkib); Tefsir-i Mevâkib Tercümesi, Kırımlı İsmail Ferruh, Ahter Matbaası, İstanbul 1318/1901, 1-2 cilt.

109 BOA, MF.MKT 627/52 (16 S 1320/25 Mayıs 1902) Yine Ehl-i Beyt'le ilgili Arapça bir eser olan Murad Buharî Tekkesi Şeyhi Süleyman el-Belhî tarafından kaleme alınan Yenâbî‘u'lMevedde'nin Ahter Matbaası'nda basılmasına dair ruhsat için bkz. BOA, MF.MKT 62/170 (4 B 1296/24 Haziran 1879). 
karar verilmiş olan yasak kitaplardandır. ${ }^{110}$ Londra'dan getirdiği yüz nüsha Arapça ve Farsça çeşitli kitapların, İngiliz postanesinden isim benzerliğinden kaynaklanan bir yanlışlık dolayısıyla Malumat matbaasına gönderilmesi neticesinde başlatılan işlemlerle Malumat matbaasından alınan kitaplar incelenmiş ve içlerinde Celcelûtiyye, Kevkeb-i Muzafferî gibi yasaklı kitapların çok sayıda nüshasına rastlanarak el konulmuştur. Mahzurlu olmayanlar ise Tahir Efendi'ye iade edilmiştir. ${ }^{111}$

Ruhsatsız basıldığı için el konulan kitaplara ise Cevdet Paşa’nın Kısâs-ı Enbiya'sı örnek olarak verilebilir. Bu kitabın çok sayıda nüshası hem matbaasında hem de kaçak olarak satışı yapılmaya çalışılırken dükkânda ele geçirilmiştir. ${ }^{112}$ Abdülhak Hâmid, Namık Kemal ve Ziya Paşa gibi dönemin çok okunan müelliflerinin eserlerinin de ruhsatsız baskıları dükkânda ele geçirilmiştir. ${ }^{113}$

Muhammed Tahir, 11 Mayıs 1325/24 Mayıs 1909 tarihli dilekçesinde, Validehan'da ve Hakkaklar Çarşısı'ndaki dükkân ve matbaasından 27 Kanun-ı sani (9 Şubat 1902) ve 13 Şubat 1317 (26 Şubat 1902) tarihinde Matbuat-1 Dâhiliye İdaresi tarafından usulsüz ve kanuna aykırı bir şekilde müsadere edilen kitaplarının aynen iadesi ya da bedelinin ödenmesini istemektedir. Bedel olarak 7000 kuruş belirlediği kitapların listesi şöyledir: ${ }^{114}$

110 BOA, MF.MKT 627/52 (16 S 1320/25 Mayıs 1902) Diğer bir örnek için bkz. BOA, MF.MKT 116/107 (3 Ş 1307/25 Mart 1890).

111 BOA, DH.MDK 248/39 (6 Ş 1320/8 Kasım 1902); BOA, DH.MDK 248/63 (11 Ş 1320/13 Kasım 1902). Ayrıca Ahter Matbaası'nın "asâr-1 muzırra tab" ve neşrini itiyad eden" şeklinde tanımlandığı bir belge için bkz. BOA, MF.MKT 213/31 (17 M 1312/21 Temmuz 1894).

112 "Cevdet Paşa merhumun telifatından olan Kısas-ı Enbiya'nın beş altı sene evvel merhum müşarunileyhin müsaadesiyle 2-3000 adedini tab' eylemesiyle bu kere tekrar tab'ına ruhsat itası için 15-20 gün mukaddem nezaret-i celilelerine müracaat ederek muamele-i resmiyesi icra olunmaksızın mahdumu Kemal Efendi ruhsat alınmış zannıyla prova olarak 5-10 formasını mürettiplere verip tab' ettirmiş ise de muahharan men edildiğini ve müfettiş-i mumaileyhe de o yolda beyan-1 keyfiyet eylediğini söylediği heyet-i tahkikiyeden ifade kılınmış" ifadeleri için bkz. BOA, MF.TTD 35/35 (12 Ş 1314/16 Ocak 1897) ve "Ahter gazetesi müdürü Tahir Efendi'nin oğlu Ali Bey’in kendi dükkanından aşırdığı tebeyyün eden üç sandık derununda Kısâs-ı Enbiya cüzlerinin hakkında” bkz. BOA, MF.TTD 37/127 (19 Ra 1315/18 Ağustos 1897).

113 Bir baskında yakalanan ruhsatsız kitapların listesi şöyledir: Abdülhak Hâmid'in Târık (20 aded), Nazife (267 aded), Tezer (1 aded), Eşber (37 aded), Sabra (3 aded), İ̧̧li Kız (2 aded); Ziya Paşa’nın Terkîb-i Bend (7 aded); Namık Kemal'in Evrâk-ı Perişan (1 aded) ve Bârika-i Zafer (78 aded). Bkz. BOA, MF.MKT 323/55 (3 M 1314/14 Haziran 1896). Ruhsatsız basılmış eserleri evinde sakladığına dair bir belge için bkz. BOA, MF.MKT $153 / 56$ (13 R 1310/2 Ocak 1893).

114 BOA, DH.MDK 154/90 (25 C 1327/14 Temmuz 1909). 


\begin{tabular}{|c|c|}
\hline Kitap İsmi & Adedi \\
\hline Baş Meselesi (?) & 6 \\
\hline Evrâk-ı Perişan & 1 \\
\hline Târîh-i Umûmî & 1 \\
\hline Kevkebül-İlm & 1 \\
\hline Doğru Yol & 2 \\
\hline$\dot{I} c ̧ l i K \imath z$ & 2 \\
\hline Sabr u Sebat & 1 \\
\hline Silistre & 1 \\
\hline Mecmua-i Letâif & 6 \\
\hline Osmanlı Kütübhanesi & 7 \\
\hline
\end{tabular}

27 Kanun-1 sani 1317/9 Şubat 1902

\begin{tabular}{|l|c|}
\hline Kitap İsmi & Adedi \\
\hline Garâibü Avâid-i Milel & 447 \\
\hline Yıldızname & 18 \\
\hline Tezer & 160 \\
\hline Evrâk-ı Perişan & - \\
\hline
\end{tabular}

\section{3 Şubat 1317/26 Şubat 1902}

Tahir'in matbaasında, gazete ilanında da ifade edildiği üzere kitap, gazete, resmi evrak ve kartvizit ${ }^{115}$ dışında takvim de bastığı görülmektedir. ${ }^{116}$

Tahir'in dükkânında Mushaf-ı şerif sattığı da bilinmektedir. Ancak bunlar çoğunlukla ruhsatsız basılan mushaflardır. ${ }^{117}$ Kur'an-1 Kerim basımına izin ve-

115 İranlı hacılardan ahbabı Han Efşar'a, 100 adet kartvizit hediye göndermiştir. Han Efşar, muhtemelen kendisi için yeni olan bu kartvizitin kullanımını da notlarında anlatmıştır. Ziyarete giderken yanında götürdüğün ve ziyaret edilen kişi evde yoksa üzerine not yazıp bıraktığın bir kart olarak tarif etmiştir. Bkz. Caferiyan, Sefernâmehâ, IV, 521.

116 BOA, MF.TTD 52/91 (19 C 1319/3 Ekim 1901).

117 “Kitapçı Tahir Efendi yedinde bulunan Mesahif-i şerifenin zabtı için bir defaya mahsus olmak üzere hediyeleri ita edilmesi sefaretçe iltimas edildiği beyan ve işar olunuyor bu babda icab 
rilmeden önce uzun yıllar boyunca İranlı matbaacı ve kitapçıların İstanbul'da ruhsatsız bastıkları ya da yurt dışından kaçak yollarla getirdikleri mushafları sattıkları bilinen bir husustur. ${ }^{118}$ Bu gayretleri mushaf basımı konusunda Matbaa-i Osmaniye'nin imtiyaz sahibi olmasından sonra da devam etmiş, İranlılar tarafından ruhsatsız olarak basılan Kur'an-1 Kerimler daha çok İran vb. Osmanlı toprağı dışında satılmak üzere gönderilmiştir. ${ }^{119}$ Zira İstanbul baskısı Kur'ân-1 Kerimler, sıhhati ve basılırken sarf edilen dikkat dolayısıyla Osmanlı toprakları dışında özellikle İran'da çok rağbet görmüştür. ${ }^{120} \mathrm{Bu}$ sebeple olsa gerek İstanbul'a uğrayan İranlı hacılara verilen hediyelerin başında mushaf gelmiştir. Tahir Efendi de Han Efşar’a İstanbul baskısı bir Kur'an-1 Kerim hediye etmiştir. ${ }^{121}$

Tahir Efendi, ayrıca İran'daki Mushaf basım tekelini üzerine almak için teşebbüste bulunmuştur. 13 Mart 1882 'de Maarif Nezareti ve Matbaa-i Osmaniye arasında yapılan bir anlaşma ile Kur'an-1 Kerim basım imtiyazı, on

eden mebaliğin mesahif-i şerife inhisar tabından kısmen müstefid olan Matbaa-i Osmaniye tarafından bir defalık olmak üzere Maarif tabiyesinin tesviyesiyle zabt olunacak mesahif-i şerifenin mümkün olduğu takdirde matbaa-i mezkurece bittashih tedavüle çıkarılması münasib gibi mutalaa edilmiş olmağla olbabda" ifadeleri için bkz. BOA, MF.TTD 24/120 (25 R 1310/16 Kasım 1892).

118 Ali Birinci, "Osmanbey ve Matbaası: Ser-Kurenâ Osman Bey’in Hikâyesine ve Matbaa-i Osmaniye'nin Tarihçesine Medhal”, Müteferrika, XXXIX, Yaz 2001/1, s. 23-24. Yine İranlı bir kitapçı olan Hacı Kasım'ın İstanbul'da ruhsatsız Kur'an-1 Kerim basımı ve satışıla alakalı hatıraları için bkz. Baylav, Hacı Kasım Efendi, s. 8-10.

119 Birinci, "Osmanbey ve Matbaası”, Müteferrika, s. 35. Yine İranlı kitapçılardan Hacı Kasım’ın 1911 yılında yüz sandık kadar Kur’an-1 Kerimler, delail-i şerifler, tefsir-i şerifleri hamilen Buhara-Semerkand-Hokand'a gittiği, orada takriben altı ay kadar kaldığı ve evvelce İstanbul'da kitapçılık yapıp Hokand'a yerleşen Buharalı Halil Efendi'ye misafir olduğu anlatılır. Bkz. Baylav, Hacı Kasım Efendi, s. 18.

120 Eminüddevle, Mekke'den hediye alırken birkaç Mushaf-1 Şerif de satın alır ve sıhhati ve basılırken sarfedilen dikkat dolayısıyla Tahranlılar'ın İstanbul ve İskenderiyede basılmış mushaflara çok rağbet ettiğini belirtir. Bkz. Caferiyan, Sefernâmehâ, VI, 485. O dönemde İstanbul'un sadece Kur’an-1 Kerim için değil diğer dini kitapların basımı için de önemli bir merkez olduğu anlaşılmaktadır: Han Ef̧̧̧ar Rumi, Urumiye’den Amerikan Keşiş Okulu’nun yönetici olarak tanıdığ Liberi'yle İstanbul'da görüşür. İstanbul'a gelişs sebebi kızlarını tahsil için Amerika’ya göndermenin yanı sıra Urumiye’ye götürmek üzere Latin harfli İncil bastırmaktır. Kendisi de İstanbul'dan üç cilt atlas ve bir tane küre satın alan Han Efşar bunları bastırdığı İncillerle bereber Urumiye’ye götürmesi için Liberi'ye emanet eder. Bkz. Caferiyan, Sefernâmehâ, IV, 528, 530-531.

121 Caferiyan, Sefernâmehâ, IV, 543. Hacı Tekânî de Osman Bey matbaasını ziyaretinde, kendisine birkaç cilt Kur'an hediye edildiğinden bahseder. Bkz. Caferiyan, Sefernâmehâ, VI, 47. 
senelik bir müddet için bu matbaaya verilmiştir. ${ }^{122}$ İki dönem daha süren bu inhisar, Tahir Efendi'nin İran Şahı'ndan böyle bir talepte bulunmasına ilham vermiş olmalıdır. Matbaacılık faaliyetleri açısından kendisine çok büyük bir atılım sağlayacak bu teşebbüsü Şah tarafından kısmen kabul görmüştür. İtimadussaltana’nın 15 Şevval 1310/2 Mayıs 1893 tarihli hatırasında anlattığına göre Tahir, sadrazama ariza yazarak iki imtiyaz talebinde bulunmuştur. Bunlardan biri İran'da Kur'an tabının inhisarının (imtiyaz hakkının) kendisine verilmesi, diğeri de on beş yıl boyunca basılacak her kitabı kendisinin basmasıdır. Şaha sunulan bu isteklerinden on beş yıl boyunca litograf baskı imtiyazının kendisine verilmesinde bir mahzur görülmemiş ancak Allah'ın kelamıyla ilgili böyle bir tekel olmasının ne kadar mahzurlu olacağını düşünmesi gerektiği bildirilerek eğer on beş yıllık tab imtiyazını istiyorsa telgraf gönderilmesi halinde hemen emrin sadır olacağı İstanbul'daki İran Sefareti aracılığıyla kendisine bildirilmiştir. ${ }^{123}$

Ahter Matbaası'nın en önemli neşir faaliyetlerinden biri de şüphesiz Farsça gazete çıkarmanın yanı sıra Farsça eserler basmaktır. Bunların çoğunluğu dil eğitimi ve edebiyatla ilgili eserler olmakla birlikte bir kısmı da sürgündeki İranlı entelektüellerin İran modernleşmesi açısından çok etkili olmuş kitaplardır. ${ }^{124}$

1880-1900 yıllarında İstanbul; Tahran, Kalküta, Tiflis ve Kahire ile birlikte hatırı sayılır düzeyde Farsça neşir faaliyetinin gerçekleştiği bir merkez konumundadır. İstanbul'un İslam toprağı olması, Avrupa'yla siyasi, kültürel, ticari bağlantısı, İran Azerbaycan'ı, Kafkasya, Mısır ve Lübnan arasındaki bağlantıyı sağlayarak İran dışındaki İranlılar için de birleştirici bir nokta olması, meşruti yönetim ve modernleşme hususlarında Osmanlı entelektüelleriyle fikri ve hissi olarak ortak bir paydaya sahip olunması gibi sebeplerle çok sayıda İranlı entelektüel İstanbul'da yaşamış ya da burası üzerinden Avrupa'ya geçiş yapmıştır. İstanbul'da mukim İranlı tüccarların maddi ve Osmanlı entelektüellerinin fikri desteğiyle gazete ve kitap neşretmek, Avrupa dillerinden tercümeler yapmak, Encümen-i Saadet gibi örgütlü siyasi faaliyetler ve İran dışındaki diğer topluluklarla özellikle

122 Matbaa-i Osmaniye'nin Kur'an-1 Kerim basımıla ilgili bkz. Birinci, “Osmanbey ve Matbaası", Müteferrika, s. 26-43.

123 Niya, İran ve Osmanî, I, 420-421.

124 Christophe Balay, "Littérature Persane en Diaspora: Istanbul 1865-1895", Les Iraniens d'Istanbul, ed. Thierry Zarcone-F. Zarinebaf-Shahr, Istanbul-Teheran, 1993, s. 177-186. 
Kahire, Berlin, Tiflis, Paris ve Londra'daki İranlı çevrelerle sürekli bir irtibat sağlamak suretiyle çok aktif hale gelmişlerdir. ${ }^{125}$

XIX. asrın sonuna kadar İstanbul'a göçen İranlılar, çoğunluğu bir şekilde Ahter gazetesiyle de irtibatlı olan Ağa Han Kirmânî gibi eski Bâbîler, Afganî gibi İslam birliği taraftarları, Malkum gibi anayasacı liberaller, Tâlibof gibi Ahundzâde'nin fikirlerine sempati duyanlar ya da Merâğaî gibi geri kalmışlıktan muzdarip vatanperverler iken XX. asrın başında gelenler ise çoğunlukla 19071911 iç savaşından kaçan siyasetçilerdir. ${ }^{126} \mathrm{Bu}$ isimlerin yayınlanan kitap ve yazılarında istibdad, iktisadi gerilik, yabancı güçlerin tahakkümü ve aynı zamanda Avrupalı devletlerin ilerlemesinin ardındaki sebepler ele alınırken açık veya örtük olarak Avrupa’nın model alınmasının gereği üzerinde durulmuştur. Sosyal hayat üzerine makaleler ve siyasi risaleler yazan modernleşme yanlısı bu kişiler, muhalif politik gruplara katılmışlar ve Tahran, Kahire, İstanbul, Tiflis ve Kalküta arasında seyahat etmişlerdir. ${ }^{127}$

Ahter'de basılan bu türden eserlere en çarpıcı örnek, İran modernleşmesi açısından oldukça etkili olan Mirzâ Abdürrahîm Tâlibof Tebrîzînnin (18341911) Kitâb-ı Abmed olarak da bilinen Sefine-i Tâlib̂̂̀ (I-II, İstanbul 1311-1312) isimli eseridir. ${ }^{128}$ Kitap gördüğü ilgi nedeniyle olsa gerek birden çok baskı yap-

125 Djamchid Behnam, "Le rôle de la Communauté Iranienne d'Istanbul dans le Processus de Modernisation de l'Iran”, Les Iraniens d'Istanbul, ed. Thierry Zarcone-F. Zarinebaf-Shahr, Istanbul-Teheran, 1993, s. 8-9.

126 Behnam, "Le rôle de la Communauté Iranienne d'Istanbul”, Les Iraniens, s. 9. XIX. asır boyunca ve XX. asrın başında İran'dan İstanbul ve diğer yerlere göç edenlerin sayıları, oranları hakkında bkz. Nategh, "Mirzâ Âqâ Khân”, Les Iraniens, s. 45-46. Mirza Ağa Han, 1891 tarihli mektubunda Mirza Malkum Han'a İstanbul'daki Babi ve Şeyhilerin ileri gelenlerini tanıtırken, "İran hükümetine karşı bir harekete başlamak hususunda diğerlerinden daha gayretli olacaklarını" ifade etmiştir. Bâbîler, Ahter gazetesiyle de işbirliği içerisindedirler. Gazetenin redaktörlerinden biri ve Tahir’in damadı Mirza Şerif Kâşânî sürgün çevrelerinde tanınmış bir Bâbî idi. Bkz. Nategh, "Mirzâ Âqâ Khân”, Les Iraniens, s. 48.

127 'Afganî; Hindistan'dan kalkıp, Kahire, İstanbul ve Tahran'dan geçerek İngiltere’ye gitmiş, Kahire'de ders vermiş, Paris’te Ernest Renan'ın bilim karşısında İslam konusundaki fikirlerine karşı bir gazete neşretmiştir. Tiflis İranlılardan Ahundzâde'nin Kahire ve İstanbul'la bağlantısı vardı ve Bombay'daki Hint Zerdüştleri Parsîlerle sürekli yazışıyordu. Alfabe reformuyla ilgili projesini sunmak üzere İstanbul'a sultanın huzuruna geldi. Malkum Tahran, İstanbul, Saint Petersbourg ve Paris'i gezdi. Londra'da bir gazete neşretti. Kırım’da yaşayan İranlı tüccar Merâgaî de eserlerini İstanbul ve Kalküta'da bastırdı. Bkz. Behnam, "Le rôle de la Communauté Iranienne d'Istanbul", Les Iraniens, s. 7-8.

128 Tâlibof'un en tanınmış eseri olup müellif ile hayali oğlu Ahmed arasında geçen yirmi iki 
mıştır. ${ }^{129}$ Hatta Tâlibof, 1319/1901 yılında Tahir'i suçlamış, 1318/1900 yılında haberi olmaksızın Sefine-i Tâlibì yi yeniden bastığını ve hakkını gasp ettiğini iddia etmiştir. ${ }^{130}$

Ahter Matbaası'nda basılan kitaplardan özellikle Farsça olanların gazetede tanıtıldığı, tabir-i caizse reklamının yapıldığı görülmektedir. Örneğin 1308 yılında Ahter Matbaası'nda basılan Ebünnasır Fethullah Han Şeybanînin şiirlerinden seçmeler; Müntehabât-ı Eşâr-ı Hikmet-Âsâr hakkında gazetede defaatle yayınlanan ilanda, Şeybanî ve eseri tanıtıldıktan sonra Tahran ve Kâşân'da hangi kitapçılardan temin edilebileceği hakkında bilgi verildiği gibi İstanbul'da da Ahter kütüphanesinde ciltsiz 15, ciltli 20 kuruş mukabilinde satıldığı, Osmanlı toprakları dışındaki yerler için ise posta ücreti ilave edileceği belirtilmiştir. ${ }^{131}$

Kitapçı Tahir, sadece neşir faaliyetleriyle değil, özellikle Avrupa'da basılan kitap ve gazetelerin Osmanlı ve İran topraklarındaki dağııımındaki katkısıyla da önemli bir figürdür. Londra’da yayınlanan Kanun gazetesinin dağıtımcılarından biridir. ${ }^{132}$ Posta yoluyla gelen gazeteleri abonelerine ulaştırdığı gibi dükkânında da satıyor olmalıdır. Tahir'in Kanun'da yayınlanan Malkum'a hitaben yazılmış bir mektubundaki “Kanun’un İstanbul'da dağıtımı yapılacağı zaman buraya gönderin. Böylesinin daha iyi olduğu açıktır. Böylece ne paketler içine koymanıza ne de başka bir tedbire gerek kalmaz. Normal bir şekilde bağlayıp fakirin adına postaneye verin, başkasının eline geçmez. Anlaştığımız gibi ben bizzat gidip alana kadar postanede İngilizler onları muhafaza ediyorlar"133 ifadeleri gazetenin hangi yolla Osmanlı topraklarına ulaşı̆̆ğını da göstermektedir.

diyalogdan müteşekkildir. Her diyalogda doğa bilimlerinden çeşitli bahisler ile Batı’da gerçekleştirilen icatlar gibi bilimsel ve vatanseverlik ve İran'ın bayındır hale getirilmesi için yapılması gerekenler gibi sosyal konuların işlendiği bu kitap, Jean Jacques Rousseau’nun Emil adlı eserinden mülhemdir. Talibof'un bu eseri, yine hayali diyaloglar usulüyle yazılmış Zeynelabidin Merâğaînin (1840-1910) İbrahim Bey’in Seyahatnamesi ile birlikte İranlıların uyanışında önemli bir role sahiptir. Tâlibof'un hayatı ve eserleri hakkında bkz. Rıza Kurtuluş, "Tâlibof”, DİA, XXXIX, 506-507.

1291319 yllı Ramazan ayında İstanbul'da bulunan hac yolcusu Reisüzzakirîn, misafir olduğu Ahmed Tebrizînnin evinde sohbet esnasında Kitâb-ı Ahmed in çok övüldüğüne tanık olunca kendisine de bir tane alınması için para vermiştir. Bkz. Caferiyan, Sefernâmehâ, VII, 329.

130 Niya, İran ve Osmanî, I, 425.

131 Ahter, XVIII/16, 27 Cemaziyelevvel 1309/29 Aralık 1891, s. 128; Abter, XVIII/17, 4 Cemaziyelahir 1309/5 Ocak 1892, s. 136.

132 Pervin, Tarih-i Ruznâme, I, 274.

133 Seyyid Ferid Kasımî, Sergozeşt-i Matbuat-ı İran Rûzgâr-ı Muhammed Şah ve Nasıruddin Şah, 
Tahir, Osmanlı toprakları dışından kitap temin ettiği gibi İstanbul'dan Osmanlı toprakları dışına da gerek kendi bastığı gerekse sattığı diğer kitapları göndermiştir. Kitap meraklısı hacılar buradayken yeni basılmış kitap edinmeye gayret etmişlerdir. ${ }^{134}$ Dükkânı ziyaret esnasında Han Efşar kendisinden birkaç cilt Farsça kitap satın aldığını kaydetmiştir. ${ }^{135}$ Tahir Efendi, İstanbul'a gelen İranlılar’a bazen kitaplar hediye etmiştir. Örneğin İstanbul'da bulunduğu süre zarfında sık görüştüğü Han Efşar’a hatıra olarak birkaç cilt kitap gönderdiği bilinmektedir. ${ }^{136}$

Tahir'in Avrupa'daki bazı kişilerle de şahsi irtibatları olduğu ve onlara kitap temin ettiği anlaşılmaktadır. Edward Browne 1888'deki Kirman gezisi esnasında Ahter'in ne kadar önemli olduğunu gözlemlediği için İngiltere'ye dönüşünde Ahter' in naşiri Tahir ile mektuplaşmaya başlamış, onun kanalıyla İstanbul ve İran'da basılan yeni kitapları temin ettiği gibi ortak tanıdıklara dair haberler almıştır. ${ }^{137}$

Sonuç olarak XIX. asrın ikinci yarısı ile XX. asrın ilk çeyreği arasında İstanbul'da yaşayan Muhammed Tahir Tebrizî ya da Osmanlı kaynaklarının isimlendirmesiyle Kitapçı Tahir Efendi'nin, sahibi olduğu Ahter Matbaası ve aynı adla yayınladığı Farsça gazete ile Osmanlı ve İran matbuat tarihinin önemli isimleri arasına adını yazdırdığı rahatlıkla söylenebilir. Bastığı kitaplar ve yayınladığı gazetenin, Osmanlı sınırlarının çok ötesinde Avrupa’dan Hindistan’a kadar dolaşımda olduğu göz önünde bulundurulduğunda yürüttüğü matbuat faaliyetlerinin fikri ve siyasi etkilerinin boyutları daha da netleşmektedir. Ayrıca söz konusu dönemde İstanbul'un, tarihi eskilere dayanan Acem tüccarların şehirdeki varlığına kıyasla yeni bir olgu olarak İranlı entelektüellerin ve siyaset adamlarının toplandığı ve

Tahran 1380, I, 586. Ahter'in yazarlarından Mirza Ağa Han Kirmânî de Kanun’un Osmanlı ve İran'daki dağıımını sağlamakla ilgilenmiştir. Ayrıca yazı da göndermiş ama daha çok İran'ın çeşitli bölgelerinden gelen haberleri Kanun'a ulaştırmakta yararlık göstermiştir. Bkz. Nategh, "Mirzâ Âqâ Khân”, Les Iraniens, s. 55. İstanbul'un İranlı hacıların güzergâhında olması, İran’da yasaklı olan yayınların dağıtımı açısından İstanbul'u çok önemli bir konuma yerleştirmiştir. Yasaklı gazetelerin başında gelen Kanun, İranlı hacıların en çok rağbet gösterdiği yayınlardandır. O kadar ki hacıların ceplerinden Kanun nüshalarının taştığı anlatılmışır. Bkz. Pervin, Tarih-i Ruznâme, I, 274.

134 Caferiyan, Sefernâmehâ, III, 105; IV, 516; IV, 533; VII, 671.

135 Caferiyan, Sefernâmehâ, IV, 533.

136 Caferiyan, Sefernâmehâ, IV, 521.

137 John Gurney, “E. G. Browne and the Iranian Community in Istanbul”, Les Iraniens d'Istanbul, ed. Thierry Zarcone-F. Zarinebaf-Shahr, Istanbul-Teheran, 1993, s. 153. 
faaliyetlerini sürdürdüğü bir merkez haline gelmesi, Tahir'in şahsının ve matbaasının daha da önem kazanmasını sağlamıştır. İstanbul'un sayıları oldukça fazla olan Acem matbaacılarından biri olarak Tahir Efendi, Osmanlı-İran siyasi ilişkilerinde ve fikri etkileşiminde önemli bir rol icra etmiştir. Bu yazı çerçevesinde ortaya koyulan, Ahter gazetesinin içeriği ve etkilerinin yanı sıra Ahter Matbaası'nda basılan kitapların tespiti, Tahir Efendi'nin Osmanlı ve İran matbuat tarihindeki rolünü tayin için gerekli bilgileri sunmaktadır.

\section{Istanbul'da Bir Acem Matbaası: Kitap̧̧ı Tahir ve Abter}

Özet - Muhammed Tahir Tebrizî ya da Osmanlı kaynaklarındaki şekli ile Kitapçı Tahir, İstanbul'a göçmüş ve ömrünün kalanını burada geçirmiş Tebrizli bir tüccar olarak özellikle İstanbul'da mukim ya da bir şekilde İstanbul'a yolu düşen hemen her İranlı’nın yakından tanıdı̆̆ı bir isimdir. Ancak yirmi yıllık bir yayın hayatına sahip, İran dışında yayınlanmış Farsça gazetelerin ilk ve en önemlilerinden biri kabul edilen Abter'i (1876-1896) yayınladığında hem Osmanlı matbuat hayatı hem de Osmanlıİran münasebetleri açısından önemli bir figür haline gelmiştir. Abter gazetesi üzerine yapılmış ve son zamanlarda giderek zenginleşen çalışmalar, gazetenin yayın hayatı boyunca sahibi ve mesul müdürlügünü üstlenmiş ve zaman zaman kendi adıyla yazılar kaleme almış Tahir hakkında ne yazık ki birkaç cümleyi geçmeyen oldukça sınırlı bilgiler sunmaktadır. Bu eksikliği gidermek maksadıyla hazırlanan makalede, Kitapçı Tahir' in biyografisiyle ilgili temel bilgilerin ortaya konması ve matbuat faaliyetlerinin bir panoramasının çizilmesinin yanı sıra İran ve Osmanlı Devleti ile ilişkilerinin ele alınması amaçlanmaktadır.

Anahtar Kelimeler: Muhammed Tahir Tebrizî, Kitapçı Tahir, Abter, Osmanlı Matbuat1 


\section{Ek: Ahter Matbaasında Basılan Kitaplar ${ }^{138}$}

1. Bahar Eğlenceleri. Seviyor muyum Seviyor mu?, Mehmed Celal, İstanbul 1319/1902, Ahter Matbaası, 14 s. MİL - ÖZEGE; 1518

2. Bahâristan, Ebü'l-Berekât Nureddin Abdurrahman b. Ahmed b. Muhammed Câmî, İstanbul 1294/1877, Ahter Matbaası, 104 s. (Farsça) HTU 04736

3. Beng ü Bâde, Mehmed b. Süleyman Fuzûlî, İstanbul 1308/1891, Ahter Matbaası, 348 s. ÖZEGE; 1841

4. Bir Mahkûmun İzdivacı yahud İstakad Köprüsü Cinayeti, Pouillet, Alexis, Çev. Ali Kemal, İstanbul 1307/1890, Ahter Matbaası, 210-250 s. (4. Kitap) ÖZEGE; 2357

5. Bir Riyâzînin Muaşakası yahud Kâmil, Dumas, Alexandre Fils, Çev. Sezaîzâde Ahmed Hikmet, İstanbul 1308/1891, Ahter Matbaası (Ahter Kitabhânesi Romanları), 106 s. BDK - ÖZEGE; 2385 - TBTK; 9046 ÖZEGE'de 29 sayfadır

6. Bir Tebessüm, Abdülkerim Hâdi, İstanbul 1310/1893, Ahter Matbaası, 29 s. BDK - ÖZEGE; 2416 - TBTK; 596

7. Bostan, Sâdî, Müşerrefüddin Ebu Abdullah Şirazî, İstanbul 1305/1888, Ahter Matbaası, 158 s. (Farş̧a)

8. Çiçek yahud Kendi Kendine Çiçekçilik, Çev. Çerkeşşeyhizâde Tevfik, İstanbul 1319/1902, Ahter Matbaası, 89+1 s. AEKMK - MİL - ÖZEGE; 3321 - TBTK; 7936; 7939

9. Dâvud el-Karsî ale'l-Emsile, Davud b. Muhammed el-Karsî, İstanbul 1304/1887, Ahter Matbaası, 32 s. TBTK; 8196 (Arapça, metnin Türkçe’si sayfa kenarlarındadır)

10. Dîvânçe-i Hanyevî Şefik Efendi, Şefik Hanyalı, İstanbul 1293/1876, Ahter Matbaası, 28 s. AEKMK - ÖZEGE; 4254

11. Dîvânçe-i Nâzım, Mehmed Nâzım, İstanbul 1308/1891, Ahter Matbaası, 21 s. ÖZEGE; 4259

138 Bu listedeki kitapların künyeleri Eski Harfli Türkçe Basma Eserler Bibliyografyası programına dayanılarak oluşturulmuş ve diğer kataloglardaki bilgilerle tamamlanmıştır. Bu listenin tekâmülündeki katkıları için Selahattin Öztürk’e teşekkür ederim. 


\section{GÜLLÜ YILDIZ}

12. Dîvân-ı Andelîb Kâşânî, el-Kaşanî, İstanbul 1313/1896, Ahter Matbaası, 212 s. (Farsça)

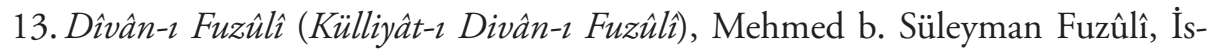
tanbul 1296/1879, Ahter Matbaası, 241+128 s. AEKMK - BDK - ÖZEGE; 4138

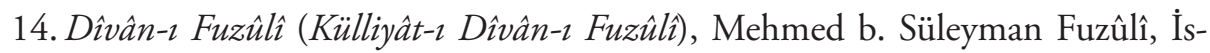
tanbul 1308/1891, Ahter Matbaası, 348 s. AEKMK - ÖZEGE; 4138 (Farsça)

15. Dîvân-ı Hâfız-ı Şirâzî, Hâfız Şemseddîn Muhammed Şîrâzî, İstanbul 1304/1886, Ahter Matbaası, 270 s. (Farsça)

16. Dîvân-ı Hâfız-ı Şirâzî, Hâfız Şemseddîn Muhammed Şîrâzî, İstanbul 13021303/1886, Ahter Matbaası, 280 s. (Farsça)

17. Dîvân-ı Hâfız-ı Şirâzî, Hâfız Şemseddîn Muhammed Şîrâzî, İstanbul 1302/1885, Ahter Matbaası, 370 s. (Farsça)

18. Divân-ı Nesimî, İmadeddin Seyyid Nesimî, İstanbul 1298/1881, Ahter Matbaas1, 186 s. BDK - ÖZEGE; 4204

19. Dürretün-Nâsihîn, Osmân b. Hasan b. Ahmed el-Şâkir el-Hûbevî Râşid, İstanbul 1300/1883, Matbaa-i Ahter, 10, 315 s. MİL - ÖZEGE; 13368 (Arapça)

20. Efsus, Nigâr bint Osman, İstanbul 1306/1889, Ahter Matbaası, 155 s. (2. K1sim) BDK - ÖZEGE; 4680

21. Efsus, Nigâr bint-i Osman, İstanbul 1308/1891, Ahter Matbaası, 61 s. (2. Baskı 1. Kısım) AEKMK - BDK - MİL - ÖZEGE; 4680

22.el-Akaidü’n-Nesefiyye, Necmeddîn Ebû Hafs Ömer b. Muhammed en-Nesefî, İstanbul 1310/1892-1893, Matbaa-i Ahter, 105 - 108 s. (Arapça)

23.el-Arzatül-Mehdiyye li'r-Ravzati’n-Nediyye, el- Hasan ed-Dağıstânî, İstanbul 1310/1893, Matbaa-i Ahter, 35 s. (Arapça)

24. el-Muğnîfi İlmi’n-Nahv, Fahreddin Ahmed b. el-Hasan el-Çârperdî, İstanbul 1310/1892, Matbaa-i Ahter, 40 s. (Arapça)

25. Emsile, İstanbul 1293/1877, Ahter Matbaası, 67-99 s. TBTK; 9944

26. Esrârǘs-Savm, Vildan Faik, İstanbul 1315/1897, Ahter Matbaası, 40 s. AEKMK - ÖZEGE; 5179 BDK - MİL 
27.es-Selâmül-Ahkâm alés-Sevâdi'l-A'zâm fi'l-Kelâm, İbrahim Hilmi b. Hüseyin el-Vâfî, İstanbul 1313/1895-1896, Ahter Matbaası, 220, s. (Arapça)

28. et-Ta'rîfât, es-Seyyid eş-Şerîf Alî b. Muhammed b. Alî el-Cürcânî, İstanbul 1308/1891, Matbaa-i Ahter, 128 s. (Arapça)

29. Fennî Eğlenceler, Tit, Tom [Arthur Good], çev. Hasan Celaleddin, İstanbul 1308/1891, Ahter Matbaası, 36 s. BDK-ÖZEGE, 5603-TBTK, 12685 Resimli.

30. Garâib-i Avâid-i Milel, Habib İsfahânî, İstanbul, 1303/1886, Ahter Matbaası, 260 s.TBTK; 11989 (Farsça Taşbaskı)

31. Gehvâre-i Edeb, Mehmed Rifat, İstanbul 1314/1897, Ahter Matbaası, 19 s. MİL - ÖZEGE; 24573 ÖZEGE; 6129 M

32. Grandok Cinayetleri, Dagon, My, Çev. Mahmut Sadık, İstanbul 1308/1891, Ahter Matbaası, 166 s. MİL - ÖZEGE; 6326 - TBTK; 7992

33. Gül Demetleri, Faik Esad, İstanbul, 1308/1891, Ahter Matbaası, 128 s. (1. Cilt) ÖZEGE; 6359 - TBTK; 10462

34. Gülşen-i Edeb, A. Hilmi, İstanbul 1317/1899, Matbaa-yı Ahter, 59 s. (Farsça)

35. Gülünçlü Efsaneler: ez Müntehabât-ı Mehmed Hilmi, Mehmed Hilmi, İstanbul 1319/1902, Ahter Matbaası, 80, 80, 80 s. (I-III Cilt) ÖZEGE; 6428

36. Gülzâr-ı Tabiat, Ahmed Hilmi, İstanbul 1315/1898, Ahter Matbaası, 70 s. ÖZEGE; 6444 - TBTK; 1496

37. Hâbnâme-i Latif, Hafız Abdüllatif Enderunî, İstanbul 1295/1878, Ahter Matbaası, 15 s. ÖZEGE; 6532 - TBTK; 619

38. Hadikatü’s-Süedâ, Mehmed b. Süleyman Fuzûlî, İstanbul 1302/1884, Ahter Matbaası, 290+2 s. ÖZEGE; 6580 - TBTK; 11172

39. Halebî-i Săĝ̀r, İbrâhîm b. Muhammed el-Halebî, İstanbul 1298/1881, Matbaatü'l-Ahter, 269, [2] s.; 23×15 cm. (Arapça Taşbaskı) (2. Baskısı 1317/1899)

40. Hallül-Esrâri'l-Ahyâr ala I'râbi İzhâri'l-Esrâr, Zeynî-zâde Hüseyin b. Ahmed Bursevî, [İstanbul] 1307/1890, Ahter Matbaası, 242 s. (Arapça)

41. Hâş̧iye alâ Şerhi'l-Akaidi'n-Nesefiyye, Hayâlî Şemseddîn Ahmed b. Mûsâ, İstanbul 1310/1892-1893, Matbaa-i Ahter, 105-108 s. (Arapça) 
42. Hatıra-i Sevda yahud İlk Göz Ağrısı: Küçük Millî Bir Hikâye, Vodinalı Hasan Remzi, İstanbul 1312/1895, Ahter Matbaası, 16 s. MİL - ÖZEGE; 7022 TBTK; 7050; 12828

43. Hevâ-yı Nesimî, Emin Feyzi, İstanbul 1308/1891, Ahter Matbaası, 119 s. MİL - ÖZEGE; 7065 - TBTK; 9720 BDK - TBTK; 10812

44. Hayat-ı Edebiyem, Yanyalı Âdem Rıza, İstanbul 1318/1901, Ahter Matbaası, 2+316 s. BDK - ÖZEGE; 7105 - TBTK; 818

45. Hazân Yaprakları, Kıyasizâde Ali Refik, İstanbul 1315/1898, Ahter Matbaası 67 s. AEKMK - ÖZEGE; 7180 - TBTK; 3630

46. Hikâyât-ı Müntehabe, Manastırlı Mehmed Rifat, İstanbul 1302/1885, Ahter Matbaası, 72 s. ÖZEGE; 7504 (2. Baskı 1313/1896)

47. Hücre-i Fakir, Mehmed Cemal, İstanbul 1312/1895, Ahter Matbaası, 18 s. ÖZEGE; 7719

48. İki Çoban, Kandiyeli Nusret Hilmi, İstanbul 1311/1894, Ahter Matbaası, 31 s. ÖZEGE; 8580

49. İki Kız, Mehmed Celal, İstanbul 1319/1902, Ahter Matbaası, 14 s. ÖZEGE; 8608

50. İki Refikin Musabahâtı, İbrahim Örfi İzmirî, İstanbul 1317/1900, Ahter Matbaası, 168+2 s. BDK - ÖZEGE; 8624

51. İlm-i Kelâmdan Kenzül-Akâid Nam Risale-i Nefîse, Süleyman Sırrı, İstanbul 1316/1899, Ahter Matbaası, 8+108+4 s. (2. Baskı) MİL AEKMK - ÖZEGE; 10563

52. İlmül-Arz, Jeyki, E. , Çeviren: Ali Fuad [Sabit], İstanbul 1309/1892, Ahter Matbaası, 112 s. BDK - ÖZEGE; 9042 Resimli

53. Kafiye, İbn el-Hâcib Cemâleddîn Ebû Amr Osmân b. Ömer, [İstanbul] 1300/1882, Ahter Matbaas1, 63 s. (Arapça)

54. Kand-i Parisî, Muallim Feyzî, İstanbul 1310/1893, Ahter Matbaası, 29 s. ÖZEGE; 10029 - TBTK; 10818

55. Kavâid-i Farisiyye - Kavâid-i Emsile-i Farisiyye - el-Emsileül-Mubtelife bi-Lisânı Farisî, Şeyh Hafız Mehmed Murad Nakşibendî, İstanbul 1294/1877, Ahter Gazetesi Matbaası, 44 s. BDK - ÖZEGE; 10402 (2. Baskı 1298/1881) 
56. Kıskançlık, Mehmed Nafi, İstanbul 1309/1892, Ahter Matbaası, 44 s. ÖZE$\mathrm{GE} ; 10$

57. Korku Belâsı, Malot, Hector Henri, Çev. Mehmed Reşad, İstanbul 1308/1891, Ahter Matbaası, 24 s. BDK - ÖZEGE; 11172

58. Kütübhane-i Cihan Esâmi-i Kütübü, İstanbul 1318/1901, Ahter Matbaası, 190 s. ÖZEGE; 11530

59. Kütübhane-i İrfan Esâmi-i Kütübü, İstanbul 1316/1898, Ahter Matbaası, 46 s.

60.Letâif-i Âsâr, Mihrî [Mihran Apikyan], İstanbul 1315/1898, Ahter Matbaası, 63 s. (2. Baskı) MİL - ÖZEGE; 11613 - TBTK; 4550 (Fransızca ve Ermenice izahatli)

61.Leylâ ve Mecnun: Manzume-i Fuzûlî, Mehmed b. Süleyman Fuzûlî, İstanbul 1296/1879, Ahter Matbaası, 128 s. ÖZEGE; 11657 - TBTK; 11189 (2. Bask1 $1308 / 1891)$

62. Macera-yı Aşk yahud Nella, Marsel, çev. M. Memduh, İstanbul 1308/1891, Ahter Matbaası, 106 s. ÖZEGE; 11869

63. Mâsiyet-i Gurur, Richebourg, Emile, Çev. Kandiyeli Nusret Hilmi, İstanbul 1312/1895, Ahter Matbaas1, 39 s. ÖZEGE; 12279

64.Medhal-i Terbiye-i Akliye, Ablâkiye, Cismaniye, Spencer, Herbert, Çev. Adanalı Ali Münif Yegena, İstanbul 1313/1896, Matbaa-i Ahter, 125 s. ÖZEGE; 12676

65.Mevâkib, Vâiz Hüseyin el-Kâşifî, Çev. İsmail Ferruh, İstanbul 13171318/1899-1900, Ahter Matbaası, 370, 357 s. (2 Cilt) ÖZEGE; 13360 (Tefsir-i Tibyan Kenarında)

66. Minhâcü̉l-Vâizîn, Midillili Mehmed Emin, İstanbul 1315/1898, Ahter Matbaas1, 8+119 s. MİLK

67. Minhatül-Mennân fi İlmi'l-Beyân, Abdullah Müderris, İstanbul 1309/1892, Matbaa-i Ahter, 10 s. (Arapça)

68. Musavver Terâcim-i Ahvâl-i Meşâhir-i Ricâl: David Livingston, Çev. Hasan Celaleddin, İstanbul 1308/1891, Ahter Matbaası, 31 s. (1. Kısım, 1. Defter) MİLK - TBTK; 8182 ÖZEGE; 3644 
69.Musavver Terâcim-i Ahval-i Meşâhir-i Ricâl: James Cook, Çev. Hasan Celaleddin, İstanbul 1308/1891, Ahter Matbaası (I. Kısım 2. Defter) 28 s. ÖZEGE; 2990 - TBTK; 7489 (1 Portre)

70. Musavver Terâcim-i Ahval-i Meşâhir-i Ricâl: Jean-François de La Pérouse, Çev. Hasan Celaleddin, İstanbul 1308/1891, Ahter Matbaası, (I. Kısım 3. Defter) 30 s. ÖZEGE; 9718 Resimli

71. Mükemmel Kiraat-ı Osmaniyye: İkinci Kısım Mubtasar Sarf, A. İrfan, İstanbul 1315/1898, Ahter Matbaası, 64 s. BDK - ÖZEGE; 25302

72. Mükemmel ve Mufassal Rehber-i Mükâtebe-i Türkiyye ve Franseviyye, Y. Fehmi, İstanbul 1317/1900, Ahter Matbaas1, 312 s. ÖZEGE; 14744

73. Mükemmel ve Muvazzah Türkçe ve Fransızca Usûl-i Mükâleme-Nouvelle Methode Guide Complet de la Conversation Turc - Français, İstanbul 1316/1899, Ahter Matbaası, 512 s. ÖZEGE; 14749 - TBTK; 3333

74. Mülteka'l-Ebhur, İbrâhîm b. Muhammed el-Halebî, İstanbul 1299/1882, Matbaa-i Ahter, 7, 232 s. (Arapça)

75. Müntehâb-ı Dâniş, Pedram, Hüseyin Dâniş, İstanbul 1309/1892, Ahter Matbaası, 92 s. (Farsça)

76. Müntehabât ez Mecmua-i Beyânât-ı Şeybânî, Ebünnasır Fethullah Han Şeybânî, topl. İsmail Basırî Karacadâğî̀, İstanbul 1308/1891, Matbaa-i Ahter, 7+312 s. (Farsça) HTU 04732

77. Nă̆amât, Faik Esad [Kayıkçı̆̆lu], İstanbul 1314/1897, Ahter Matbaası, 19 s. BDK, ÖZEGE; 15067, TBTK; 4481 (Sıhhat Mecmuası ilâvesi)

78. Nahiv Cümlesi, İstanbul 1294/1877, Matbaa-i Ahter, 63 s. (Arapça)

79. Nevzuhur Şarkılar, İstanbul 1307/1890, Ahter Matbaası, 31 s. (2. Baskı) ÖZEGE; 15456

80.Öksüz, Hasan Celaleddin, İstanbul 1308/1891, Ahter Matbaası, 46 s. ÖZEGE; 16063 - TBTK; 12686

81.Perviz-i Nigâriş-i Parsî, Gazvinî, Muhammed Rıza Hân Afşâr, İstanbul 1299/1882, Ahter Matbaası, $119+6$ s. (Farsça) (2. Baskısı 1300/1883)

82.Risale-i Ed'iye, Mehmed Tevfik, İstanbul 1300/1883, Ahter Matbaası, 15 s. ÖZEGE; 16894 
83. Risale-i Heyet-i Cedide, Flammarion, Camille Hanbaba, İstanbul1312/1894-1895, Ahter Matbaası, 230 s.: res. (Farsça)

84. Risale fi Ebvâbi't-Tasrîf, Zeynî-zâde Hüseyin b. Ahmed Bursevî, İstanbul 1304/1887, Matbaa-i Ahter, 1 - 24 s. (Arapça)

85. Riyâz-ı Asfiya, Kâzım Paşa, İstanbul 1296/1878, Ahter Matbaası, 13 s. MİLK ÖZEGE; 17012 Taşbaskı

86. Rubâiyyât-ı Hazreti Mevlânâ, Mevlânâ Celâleddin Rumî, İstanbul 1312/1895, Matbaa-i Ahter, 400 s. BDK (Farsça)

87.Sanihâtım, Vodinalı Hasan Remzi, İstanbul 1317/1900, Ahter Matbaası, $52 \mathrm{s.}$ TBTK; 12829 AEKMK - MİL - ÖZEGE; 17540

88. Sefine-i Tâlibî yâ Kitâb-ı Ahmed, Mirzâ Abdürrahîm Tâlibof Tebrî̀înin (18341911), İstanbul 1311-1312, Ahter Matbaası, 243, 144 s. (I-II cilt) (Farsça) (1314/1897 ve 1318/1900 yılında tekrar baskı)

89.Sergüzeşt-i Mari Kraliçe ve Kızları, Çev. Esad, İstanbul 1296/1879, Ahter Matbaası, 223 s. MIL - ÖZEGE; 17797 - TBTK; 10286 (TBTK'da yazar Eşref olarak görünmektedir)

90. Sı̆̆ır Yetiştirmek ve Bakmak Usûlü: En Faydalı Malûmât Nelerdir?, Spencer, Herbert, Çev. Adanalı Ali Münif Yegena, İstanbul 1313/1897, Matbaa-i Ahter, 125 s. MİL

91. Sihhatnümâ-yı Etfâl yahud Validelere Rehnümâ, Ahmed Abdullah, İstanbul 1317/1900, Ahter Matbaası, 169 s. BDKÖZEGE; 17977 - TBTK; 1052 Resimli

92. Siper-i Zelzele: Paratremblements de Terre, Resul Mesti, İstanbul 1319/1903, Ahter Matbaası, 48 s. BDK - ÖZEGE; 18103 MILLK Resimli

93.Şafak Kütübhanesi Esâmi-i Kütübü, İstanbul 1328[1318/1901], Ahter Matbaası, 190 s. HTu 18830

94.Şerhü Talimi'l-Müteallim, İbrahim b. İsmail, İstanbul 1309/1892, Matbaa-i Ahter, 144 s. (Arapça)

95.Şerhül-Akâidi’n-Nesefiyye, Mesud b. Ömer et-Taftâzâni, İstanbul 1310/18921893, Matbaa-i Ahter, 105 - 108 s. (Arapça) 
96. Şerhü'l-Emsileti'l-Muhtelife, Zeynî-zâde Hüseyin b. Ahmed Bursevî, İstanbul 1304/1887, Matbaa-i Ahter, 1 - 24 s. (Arapça)

97. Şikayetnâme, Fuzûlî, İstanbul 1926, Ahter Matbaası, 107-128 s.

98. Talimül-Müteallim Tarika't-Teallüm, Burhâneddîn ez-Zernûcî, İstanbul 1309/1892, Matbaa-i Ahter, 144 s. (Arapça)

99. Tedrîs-i Lisân-i Fransevî yani Kavâid-i Sarfiye ve Nabviyenin Tatbikatıyla Beraber Usûl-ı Tercüme ve Inşa ve Mükâleme: Enseignement Mèthodique de la Langue Française, Wiesenthale, W., İstanbul 1308/1891, Ahter Matbaası, 326 s. BDK - ÖZEGE; 20227 (2. Baskı 1315/1898)

100. Tefsir-i Tibyan, çev. Mehmed Ayıntabî, İstanbul 1317-1318/1900, AhterÂlem- Ârif Efendi Matbaaları, 307, 357 s. (I-II cilt) BDK ÖZEGE; 20688 (Bu kitabın kenarında Tefsir-i Mevâkib vardır)

101. Tefsiru Yâsin, Hammâmizâde, Ebü’l-Hasan Ali b. İsmail, İstanbul 1294/1877, Matbaa-i Ahter, 48 s. (Arapça)

102. Tenbîhü's-Sıbyan, Mehmed Hüseyin el-Ensarî, 1298/1881, Ahter Matbaası, 138 s. BDK

103. Tercüme-i Telemak, Fènelon, François de Salignac de la Mothe, Çeviren: Yusuf Kamil Paşa, İstanbul 1299/1882, Ahter Matbaası, 16+318 s. (3. Baskı) ÖZEGE; 20687 BDK - TBTK; 10655

104. Terkîb-i Bend-i Vehbi Zari, Vehbi Zari [Derviş Ali Beyzâde Abdülvehhab], İstanbul 1297/1880, Ahter Matbaası, 1 + 13 s. ÖZEGE; 20726

105. Tetebbuât ve Müstahzarâtım, Halil Rüşdü [Akır], İstanbul 1315/1898, Ahter Matbaası, 3 defter, 48 s. TBTK; 2843 ÖZEGE; 20893 BDK

106. Tuhaf Fıkraları, Hamâmizâde İhsan, İstanbul 1317/1900, Ahter Matbaası, (Yeni Cep Kütübhanesi, Aded: 1) 16 s. ÖZEGE; 21226

107. Tuhfe-i Sabri an Lisân-ı Bulgarî, Mustafa Sabri, İstanbul 1296/1879, Ahter Matbaası, 44 s. ÖZEGE; 21250

108. Tuhfetül-Emsâl, Mehmed Refî, İstanbul 1311/1894, Ahter Matbaası, 88 s. BDK

109. Tuhfetül-İhvân, Mustafa b. İbrahim, İstanbul 1300/1883, Matbaa-i Ahter, 159 s. (Arapça) 
110. Usûl-i Farisî, Muallim Feyzî, İstanbul 1299/1882, Ahter Matbaası, (Kitabhane-i Sudinin Mekteb Külliyatı) 2+96 s. ÖZEGE; 22128 - TBTK; 10824 (Farsça)

111. Usûl-i Krraat-ı Osmaniyye, Bağdadlı İsmail, İstanbul 1311/1894, Ahter Matbaası, 17+1 s. ÖZEGE; 22193 - TBTK; 5493

112. Vezâif-i Etfâl, Mustafa Hami Paşa, İstanbul 1294/1877, Ahter Matbaası, 128 s. ÖZEGE; 22578 (sonraki baskilar 1302/1885 ve 1306/1889)

113. Yenabiül-Mevedde, el-Belhî, Süleyman b. İbrahim Baba Kelan el-Kunduzî, Darülhilafeti'l-Aliyye [İstanbul] 1302/1885, Matbaatü Ahter, 10, 3527 s. (Arapça)

114. Yeni Şarkılar, İstanbul 1300/1883, Ahter Matbaası 16+16, 16 s. Cüz 1-7. ÖZEGE; 23247

115. Zavallı Jilber yahud Bir Mahkûmun Zevcesi, Mehmed Şakir, İstanbul 1307/1890, Ahter Matbaası, 47 s. MİL - ÖZEGE; 23645

116. Zemzeme-i Sevda, Topl. İhsan, İstanbul 1317/1900, Ahter Matbaası (Yeni Cep Kütübhanesi, Aded: 215 s.) ÖZEGE; 23694

117. Zengin İzdivac, Malot, Hector, Çev. Ahmed Reşad, İstanbul 1308/1891, Ahter Matbaası, 80 s. ÖZEGE; 23698

\section{Kaynakça}

Dâhiliye Nezareti Matbuat-1 Dâhiliye Kalemi Evrakı (DH.MDK) 154/90; 220/114; $220 / 88 ; 220 / 91 ; 221 / 43 ; 228 / 120 ; 230 / 86 ; 230 / 87 ; 231 / 160 ; 237 / 136 ; 248 / 39$; $248 / 63 ; 257 / 48$.

Dâhiliye Nezareti Mektubi Kalemi Evrakı (DH.MKT) 1985/65.

Maarif Nezareti Mektubi Kalemi Evrak1 (MF.MKT) 26/123; 62/170; 73/79; 74/11; $116 / 107 ; 145 / 10 ; 153 / 56 ; 213 / 31 ; 323 / 55 ; 615 / 22 ; 627 / 52$.

Maarif Nezareti TelifTercüme Dairesi Evrakı (MF.TTD) 24/120; 35/35; 37/127; 45/126; $52 / 91$.

Şura-yı Devlet Evrakı (ŞD) 218/60; 2970/31.

Yıldız Tasnifi Mütenevvia Evrakı (Y.MTV) 254/41. 
Ahter, I/1, 16 Zilhicce 1292/13 Ocak 1876; XV/1, 11 Safer 1306/12 Eylül 1888; XVI/24, 19 Cemaziyelahir 1307/10 Şubat 1890; XVIII/1, 11 Safer 1309/15 Eylül 1891; XXII/1, 2 Muharrem 1313/25 Haziran 1895

Salnâme-i Nezaret-i Maarif-i Umumiyye, 1316/1898.

Salnâme-i Nezaret-i Maarif-i Umumiyye, 1317/1899.

Salnâme-i Nezaret-i Maarif-i Umumiyye, 1318/1900.

Salnâme-i Devlet-i Aliyye-i Osmaniyye, 1294/1877.

Salnâme-i Devlet-i Aliyye-i Osmaniyye, 1317/1899.

Salnâme-i Devlet-i Aliyye-i Osmaniyye, 1318/1900.

Salnâme-i Devlet-i Aliyye-i Osmaniyye, 1319/1901.

Salnâme-i Devlet-i Aliyye-i Osmaniyye, 1320/1902.

Baylav, Naşid: İlk Türk Kitapçılarından Hacı Kasım Efendi, İstanbul 1962.

Behnam, Djamchid: "Le rôle de la Communauté Iranienne d'Istanbul dans le Processus de Modernisation de l'Iran", Les Iraniens d'Istanbul, ed. Thierry Zarcone-F. Zarinebaf-Shahr, Istanbul-Teheran, 1993, s. 3-10.

Balay, Christophe: “Littérature Persane en Diaspora: Istanbul 1865-1895”, Les Iraniens d'Istanbul, ed. Thierry Zarcone-F. Zarinebaf-Shahr, Istanbul-Teheran, 1993, s. 177186.

Birinci, Ali: "Osman Bey ve Matbaası: Ser-kurenâ Osman Bey'in Hikâyesi ve Matbaa-i Osmaniye’nin Tarihçesine Medhal”, Müteferrika, Sayı: 39, Yaz 2011/1, s. 3-148.

......, "Osmanlı Devleti'nde Matbuat ve Neşriyat Yasakları Tarihine Medhal", TALID, VII, 4/2006, 291-349.

Blochet, E.: Catalogue des Manuscrits Persans, IV, Paris 1934.

Browne, Edward G.: A Literary History of Persia, Cambridge 1930, I-IV.

......, The Press and Poetry of Modern Persia, Cambrigde 1914.

Caferiyan, Resul (ed.): Sefernâmehâ-yi Hacc-ı Kâcârî, Tahran 2011, I-VIII.

Chelkowski, Peter: "Edward G. Browne's Turkish Connexion", Bulletin of the School of Oriental and African Studies, XLIX, 1986, s. 25-34.

Dığıroğlu, Filiz: "İstanbul-Tebriz Ticaret Hattında Validehan (XIX-XX. Yüzyıl)”, Türk Kültürü İncelemeleri Dergisi, sayı 31, güz 2014, s. 69-112.

......, Dersaadet'te Bir Acem Kitapçı: Kitap-Füruş Hacı Hüseyin Ağa, İstanbul 2014.

Gurney, John: "E. G. Browne and the Iranian Community in Istanbul”, Les Iraniens d'Istanbul, ed. Thierry Zarcone-F. Zarinebaf-Shahr, Istanbul-Teheran, 1993, s. 149175. 
Kasımî, Seyyid Ferid: Sergozeşt-i Matbuât-ı İran Rûzgâr-ı Muhammed Şah ve Nasıruddin Şah, Tahran 1380, I-II.

Koloğlu, Orhan: “Un Journal Persan d'Istanbul: Akhtar”, Les Iraniens d'Istanbul, ed. Thierry Zarcone-F. Zarinebaf-Shahr, Istanbul-Teheran, 1993, s. 133-140.

Kurtuluş, Rıza: “Tâlibof”, DİA, XXXIX, 506-507.

......, 1906-1911 İran Meşrutiyet Hareketinde Osmanlı Etkisi, Marmara Üniversitesi Ortadoğu Araştırmaları Enstitüsü, Yayınlanmamış Doktora Tezi, İstanbul 2010.

Lawrence, Tanya Elal: Akhtar: A Persian Language Newspaper Published in Istanbul and The Iranian Community of The Ottoman Empire in The Late Nineteenth Century, İstanbul 2015.

Nategh, Homa: "Mirzâ Âqâ Khân, Sayyed Jamâl al-Din et Malkom Khân à Istanbul (1860-1897)", Les Iraniens d'Istanbul, ed. Thierry Zarcone-F. Zarinebaf-Shahr, Istanbul-Teheran, 1993, s. 45-60.

Niya, Rahim Reis: Iran ve Osmanî der Âsitane-i Karn-i Bistom, Tahran 1328, I-II.

Pervin, Nasıruddin: Tarih-i Ruznâme-Nigârî-i Iraniyân ve Diger Parsi-Nevisiyan, Tahran 1377, I-II.

Pistor-Hatam, Anja: "The Persian Newspaper Akhtar as a Transmitter of Ottoman Political Ideas", Les Iraniens d'Istanbul, ed. Thierry Zarcone-F. Zarinebaf-Shahr, IstanbulTeheran, 1993, s. 141-147.

Sasani, Han Melik: Payitabtın Son Yıllarında Bir Sefir, çev. Hakkı Uygur, İstanbul 2006.

Sefernâme-i Hacı Pirzâde, haz. Ferman Fermaiyan, Tahran 1343.

Strauss, Johann: “La Présence Diplomatique Iranienne a` Istanbul et dans les Provinces de l'Empire Ottoman, 1848-1908", Les Iraniens d'Istanbul, ed. Thierry Zarcone-F. Zarinebaf-Shahr, Istanbul-Teheran, 1993, s. 11-32.

Vejdani, Farzin: “Transnational Baha'i Print Culture: Community Formation and Religious Authority, 1890-1920", Journal of Religious History, Vol. 36, No. 4, December 2012, s. 499-515.

Yıldız, Güllü: “İranlı Hacıların Gözüyle İstanbul'u Temâşầ, Marmara Üniversitesi İlâhiyat Fakültesi Dergisi, sy. 51, Aralık 2016, s. 135-160.

Zarinebaf, Fariba: “Alternatif Moderniteler: Osmanlı İmparatorluğu ve İran'da Meşrutiyetçilik”, Dîvân: Disiplinler Arası Çalışmalar Dergisi, XIII/24 (2008/1), s. 47-78. 